\title{
Zinc Hyperaccumulation in Plants: A Review
}

\author{
Habiba Balafrej ${ }^{1, * \mathbb{C}}$, Didier Bogusz ${ }^{2}$, Zine-El Abidine Triqui ${ }^{1}$, Abdelkarim Guedira ${ }^{1}$, \\ Najib Bendaou ${ }^{1}$, Abdelaziz Smouni ${ }^{1}$ (i) and Mouna Fahr ${ }^{1, *(\mathbb{D}}$
}

1 Laboratoire de Biotechnologie et Physiologie Végétales, Centre de biotechnologie végétale et microbienne biodiversité et environnement, Faculté des Sciences, Université Mohammed V de Rabat, 10000 Rabat, Maroc; z.triqui@um5s.net.ma (Z.-E.A.T.); a.guedira@um5s.net.ma (A.G.); n.bendaou@um5s.net.ma (N.B.); a.smouni@um5s.net.ma (A.S.)

2 Equipe Rhizogenèse, Institut de Recherche pour le Développement, Unité Mixte de Recherche Diversité Adaptation et développement des Plantes, Université Montpellier 2, 34394 Montpellier, France; didier.bogusz@ird.fr

* Correspondence: habiba.balafrej@gmail.com (H.B.); m.fahr@um5s.net.ma (M.F.); Tel.: +21-2537775461 (H.B. \& M.F.)

Received: 2 March 2020; Accepted: 14 April 2020; Published: 29 April 2020

check for updates

\begin{abstract}
Zinc is an essential microelement involved in many aspects of plant growth and development. Abnormal zinc amounts, mostly due to human activities, can be toxic to flora, fauna, and humans. In plants, excess zinc causes morphological, biochemical, and physiological disorders. Some plants have the ability to resist and even accumulate zinc in their tissues. To date, 28 plant species have been described as zinc hyperaccumulators. These plants display several morphological, physiological, and biochemical adaptations resulting from the activation of molecular $\mathrm{Zn}$ hyperaccumulation mechanisms. These adaptations can be varied between species and within populations. In this review, we describe the physiological and biochemical as well as molecular mechanisms involved in zinc hyperaccumulation in plants.
\end{abstract}

Keywords: zinc; hyperaccumulation; bioavailability; tolerance; molecular mechanisms; plants

\section{Introduction}

Zinc (Zn) is the second most abundant transition metal in living organisms after iron [1]. Zn plays important roles in plant development, reproduction, and signaling due to its structural, catalytic, and activating functions [2]. Zn acts also as a cofactor for many enzymes, such as carbonic anhydrase, carboxypeptidase, and Zn-superoxide dismutase [3-5].

For most crops, the typical $\mathrm{Zn}$ concentration required for proper growth is approximately between 15 and $20 \mathrm{mg} \mathrm{kg}^{-1}$ dry weight [6]. Beyond these concentrations, $\mathrm{Zn}$ can be toxic to flora, fauna, and humans [7]. In plants, $\mathrm{Zn}$ toxicity increases with its bioavailability. The latter depends on different factors, such as $\mathrm{pH}$, root exudate, microbial communities, and soil organic matter, that limit or promote its bioavailability [8-10]. Excess Zn may alter plant development [11,12]. However, some plants have developed the ability to grow in environments with high $\mathrm{Zn}$ concentrations where sensitive ones cannot [13]. Some of these plants, known as hyperaccumulators, have the ability to accumulate high amounts of $\mathrm{Zn}$ in their aerial parts [11-13]. To understand $\mathrm{Zn}$ hyperaccumulation mechanisms, at physiological, biochemical, and molecular level, scientists have firstly identified model plants as $\mathrm{Zn}$ hyperaccumulators [14,15]. To date, only 28 species have been described as $\mathrm{Zn}$ hyperaccumulators.

In this review, we discussed the different sources of $\mathrm{Zn}$ contamination and parameters that can affect its bioavailability. We also reviewed the different studies underlying the effect of $\mathrm{Zn}$ excess on plant growth and development. Morphological, physiological, biochemical, and molecular adaptations to $\mathrm{Zn}$ in hyperaccumulator plants were also tackled in this review. 


\section{Sources and Bioavailability of Zinc}

Zn occur naturally in soil from pedogenetic processes of mother rocks' leaching [16]. Natural background levels of $\mathrm{Zn}$ in water, soil, and rocks change over a wide range of concentrations. Thus, its background in soils and rocks is typically between 10 and $300 \mathrm{ppm}$ while its concentration in rivers is less than 0.01-0.2 ppm [17]. A small part of $Z n$ in soil, rock, and sediments is constantly removed and transported through the environment by natural erosion processes [18]. Natural phenomena, such as volcanic eruptions, also contribute to the continuous cycling of Zn. Natural emissions of $\mathrm{Zn}$ are estimated to reach 5.9 million tons each year [13].

In addition to natural occurrence, industrial activities provide additional sources of $\mathrm{Zn}$ contamination. $\mathrm{Zn}$ is one of the major pollutants that are released into the environment as a result of industrial activities, mining, smelting, and sewage sludge, as well as persistent use of $\mathrm{Zn}$ fertilizers [19]. $\mathrm{Zn}$ pollution can be also generated by anthropogenic activities, such as municipal wastewater discharge, coal-burning power plants, manufacturing processes involving zinc, and atmospheric fallout $[16,20]$. The $\mathrm{Zn}$ concentration in soil is closely linked to its different sources. However, its toxicity remains dependent on factors that limit or promote its availability.

In soils, zinc can be present in different forms, mainly as a free ion $\left(\mathrm{Zn}^{2+}\right.$ and $\left.\mathrm{ZnOH}^{+}\right)$or complexed with organic matters. Zn also occurs in the colloidal fraction of the soil coupled with humic compounds, iron and aluminum hydrated oxides or as a constituent of secondary minerals and insoluble complexes $[21,22]$. The most predominant forms of $\mathrm{Zn}$ found in the colloidal fraction are the neutral sulphate $\mathrm{ZnSO}_{4}$ and phosphate $\mathrm{ZnHPO}_{4}$ [22].

$\mathrm{Zn}$ bioavailability is predominantly controlled by adsorption-desorption phenomena and liquid/solid solubility relations [23]. The bioavailability of $\mathrm{Zn}$ depends on many factors, namely $\mathrm{pH}$, chemical and mineralogical composition, soil organic matter, root exudates, and rhizospheric microbial communities [8-10,23].

Soil $\mathrm{pH}$ represents the major factor that influences $\mathrm{Zn}$ distribution and speciation in soil because it affects $\mathrm{Zn}$ solubility and sorption in the soil solution [24]. Usually, $\mathrm{Zn}$ is more bioavailable at an acid $\mathrm{pH}$ than at an alkaline $\mathrm{pH}[25,26] . \mathrm{Zn}^{2+}$ is the predominating form of $\mathrm{Zn}$ at a neutral $\mathrm{pH}$ (below 7.7) while $\mathrm{ZnOH}^{+}$can be found at $\mathrm{pH}$ 7.7-9.1. Above it, the neutral form $\mathrm{Zn}(\mathrm{OH})_{2}$ is predominant [22]. Leitenmaier and Küpper, and DalCorso $[27,28]$ demonstrated that an increase in Zn's bioavailability at a high $\mathrm{pH}$ can be explained by a decrease of the intra- and intermolecular hydrogen bonds in humic acid molecules. A small change in the soil $\mathrm{pH}$ has a great impact on $\mathrm{Zn}$ 's solubility in soil.

The bioavailability of $\mathrm{Zn}$ is negatively affected by the presence of phosphatic clay [29] and its coagulation with different mineral structures of the soil, sediment, and water [8]. Cao et al. [30] demonstrated that the presence of phosphate in the soil also affects $\mathrm{Zn}$ solubility in water, due to $\mathrm{Zn}$ ions' sorption into the soil mineral compounds. However, Hafeez et al. [31] reported that soils with higher phosphate levels, either from native phosphate or due to the application of phosphate fertilizers, can reduce Zn's availability. This suggests that phosphate application may be one of the solutions that reduces $\mathrm{Zn}$ 's bioavailability in the soils.

Organic matter plays a key role in governing Zn's availability in the soil. It improves Zn's availability by releasing $\mathrm{Zn}$ with time and through changes in the physicochemical properties of the soil, which increases its uptake by roots [32]. Clemente et al. [33] found that extractable $\mathrm{Zn}$ increases with an elevated organic carbon content in the soil. Organic matter amendment increases Zn's solubility in soils. Exogenous organic matter releases free $\mathrm{Zn}$ into soil solutions, which enables $\mathrm{Zn}$ to form complexes with other soil components, and thus change its original solubility and mobilization [34]. However, if the organic matter content in the soil is too high, like in peat and muck soils, this can contribute to a decrease of Zn's availability due to Zn binding on the solid state of humic substances [31].

It is well known that roots interact with the rhizosphere. Indeed, root activity induces several modifications in the rhizospheric soil proprieties, like the $\mathrm{pH}$, microbial activity, chemical equilibrium, mobility, and bioavailability $[33,35]$. These changes are induced by root exudates that change the nutrients and metal supplies. Root exudates are released by root cells in the soil, including low molecular 
weight compounds (amino acids, organic acids, sugars, phenolic compounds) and compounds of high molecular weight (polysaccharides and proteins) [36,37]. Medas et al. [38] reported that root exudates facilitate Zn silicate uptake in Euphorbia pithyusa L. In Arabidopsis halleri, Tsednee et al. [39] observed that roots release nicotianamine (NA), a main chelator, which has a beneficial effect on improving Zn's solubilization and thus $\mathrm{Zn}$ accumulation. In Hordeum vulgar, Lolium perenne $\mathrm{L}$., and different dicots species, roots produce organic molecules that have the ability to form complexes with $\mathrm{Zn}$, thus promoting its mobility [40-42].

Rhizospheric microbial communities are an important factor affecting the bioavailability of the soil's indigenous and exogenous $\mathrm{Zn}$ [43]. Among the bacteria, species belonging to the genera Acinetobacter, Bacillus, Gluconacetobacter, and Pseudomonas have been described as Zn solubilizers [44]. The mechanisms by which rhizosphere microflora may improve Zn's solubilization include a reduction of the soil $\mathrm{pH}, \mathrm{Zn}$ chelation or improvement of root growth. These mechanisms differ from one microorganism to another. Some microorganisms may use one of these mechanisms while others can improve $\mathrm{Zn}$ acquisition in plant by using more than one mechanism [26]. Furthermore, the presence of microorganisms in the rhizosphere, in particular mycelium fungi, increases plants' tolerance to abiotic stress [43]. For example, in Nocceae praecox, arbuscular mycorrhizal colonization increased the $\mathrm{Zn}$ shoot to root ratio, which reflects better Zn uptake by the root system [45].

\section{Effect of Zn Excess on Plant Development}

$\mathrm{Zn}$ is an essential nutriment for all organisms. It is required for the activation of many enzymes in plant cells, such as alcohol dehydrogenase, carbonic anhydrase, and RNA polymerase $[4,46]$. $\mathrm{Zn}$ is also involved in biomembranes' stabilization by interacting with the phospholipids and sulfhydryl groups of membrane proteins [47]. It can contribute to proteosynthesis, metabolism of carbohydrates, and lipid and nucleic acid synthesis $[48,49]$. Furthermore, $\mathrm{Zn}$ plays a crucial role in oxygen radical production as well as their detoxification. Zn participates in $\mathrm{Cu}-\mathrm{Zn}$-SOD enzyme synthesis, a key enzyme involved in the removal of toxic $\mathrm{O}^{-}$radicals, which can be harmful to membrane lipids and proteins $[4,47]$. Cu-Zn-SOD is essentially localized in chloroplasts; in some plants, it is found in the thylakoid lumen whereas in others it is bound to the thylakoid [50]. At high concentrations, $\mathrm{Zn}$ becomes toxic. Jain et al. [51] demonstrated that in A. thaliana, treatment with $0.075 \mathrm{mM}$ of $\mathrm{Zn}$ did not affect plant development, whereas at concentrations above $0.1 \mathrm{mM}, \mathrm{Zn}$ became toxic.

Zn's toxic effects depend on its external bioavailable concentration, exposure time, plant genotype, and step of plant development. The most obvious symptoms of $\mathrm{Zn}$ toxicity reported in plants are the inhibition of growth, and chlorosis of young leaves (probably the consequence of lower uptake of $\mathrm{Fe}^{2+}$ and $\mathrm{Fe}^{3+}$ ), and can lead, in some cases, to cell death [52]. Growth alteration is a consequence of mitosis inhibition. It was reported that excess $\mathrm{Zn}$ induces a significant reduction in the mitotic index in Saccharum spp and Triticum aestivum L, respectively [53,54]. This reduction in mitotic activity could be due to the inhibition of DNA synthesis.

\subsection{Effect of $Z n$ Excess on Seed Germination}

Seed is the first phase in the plant life cycle. Studying the effect of excess $\mathrm{Zn}$ in seed germination is crucial for understanding Zn's effects on plant growth and development. The effect of $\mathrm{Zn}$ on seed germination depends on the plant species and Zn concentration. It was not significant in Macrotyloma uniflorum and in Pinus sylvestris at $0.1 \mathrm{mM}$, but a delay in germination was observed [55,56]. The same results were reported in Eruca sativa at $5 \mathrm{mM}$ of $\mathrm{Zn}$, and Coriandrum sativum and Nigella sativa at $2 \mathrm{mM}$ of $\mathrm{Zn}$. This finding was attributed to the protective effect of seed tegument, which offers protection against metal stress before germination [57-59]. However, other studies showed that higher concentrations of $\mathrm{Zn}$ considerably reduce the germination of plants, including Vigna unguiculata, Cassia angustifolia, and Glycine max [60-62]. Bae et al. [63] observed that the presence of high concentrations of $\mathrm{Zn}$ reduced the germination rate in Trifolium arvense. Seed teguments seem to play an important role in the protection of seeds against high $\mathrm{Zn}$ concentrations. 


\subsection{Effect of Zn Excess on Root Development}

$\mathrm{Zn}$ exposure induced significant modifications in the root system architecture [64]. In fact, several studies have revealed that plants exposed to high metal concentrations showed changes in the root morphology and developed higher root branching with a marked curvature and a higher branching percentage in the contact area with the metal [65-68]. Zn stress also induces a reduction of the primary root length [69]. The repression of root elongation was explained by the inhibition of cell proliferation and subsequent elongation [59]. Li et al. [70] revealed that a reduction of root growth is linked to a significant loss of cell viability in the root tips and to an increased level of lignification in Triticum aestivum seedlings exposed to high $\mathrm{Zn}$ concentrations. This finding was also reported in Jatropha curcas [71] and Citrus reticulata Blanco [72]. The observations of a root ultrastructure of Phyllostachys pubescens showed that the addition of $0.2 \mathrm{mM} \mathrm{Zn}$ had serious effects on root epidermal and root tip cells. Microscopic observations revealed the presence of crystals in the xylem parenchyma, which might obstruct nutrient transport and thus can reduce root growth [73]. In Senna multijuga and Erythrina crista-galli, a high Zn concentration in the soil induced a linear decrease of the root-specific superficial area, which affects their growth and reduces the capacity of water and nutrient absorption [74]. Beta vulgaris $\mathrm{L}$ plants grown with a $\mathrm{Zn}$ excess are defective in root growth, displaying a brown color with short lateral roots. In this plant, high excess $\mathrm{Zn}$ induces a shutdown of the general metabolism in the roots due to a decrease in all of the steps of aerobic respiration [75].

Reactive oxygen species (ROS), such as hydrogen peroxide $\left(\mathrm{H}_{2} \mathrm{O}_{2}\right)$ and superoxide anion $\left(\mathrm{O}_{2}{ }^{-}\right)$, are commonly generated in response to excess $\mathrm{Zn}$ in the roots of several plant species [76-78]. In B. napus, $0.3 \mathrm{mM}$ of $\mathrm{Zn}$ induced a strong accumulation of $\mathrm{H}_{2} \mathrm{O}_{2}$ in the roots [79], which can lead to serious cell damage [76-78]. However, in the resistant $B$. juncea, ROS levels remained low in the root of $\mathrm{Zn}$-treated plants. This suggests that $\mathrm{Zn}$ sensitivity is determined by the level of oxidative species produced in Brassica genera [79].

\subsection{Effect of Zn Excess on Aerial Parts Development}

In the aerial parts of plants, one of the first mechanisms to be affected by zinc toxicity is photosynthesis [80]. With an increasing Zn concentration, photosystem II (PSII) efficiency parameters declined [78]. For example, in Solanum lycopersicum, toxic concentrations of Zn (43 ppm) affected plant growth and caused leaf chlorosis, due to the adverse effect of a high $\mathrm{Zn}$ concentration on photosynthetic electron transport, loss of plasma membrane integrity, and a decrease of bio-membrane permeability, which result in photosynthesis impairment [81]. The same deterioration was also observed in Halimione portulacoides, which is considered as $\mathrm{Zn}$ hypertolerant, when cultivated at $70 \mathrm{mmol} \mathrm{L}^{-1}$ of $\mathrm{Zn}$ [82]. Monnet et al. [83] linked a lack of photosynthetic activity with the production of reactive oxygen species, such as $\mathrm{O}_{2}{ }^{-}$or $\mathrm{H}_{2} \mathrm{O}_{2}$, which leads to disassembly of the thylakoids. Azzarello et al. [84] found that antennae pigments' impairment due to an excessive concentration of $\mathrm{Zn}$ may disturb the maximum PSII photochemistry. This decrease in PSII quantum yields was mostly due to a decrease in the basal fluorescence [83]. Beta vulgaris L plants grown with excess $\mathrm{Zn}$ showed signs of stress, such as their leaf edges rolled inwards. High excess $\mathrm{Zn}$ can induce a shutdown of the general metabolism in sugar beet as a result of decreased PSII efficiency [75]. In Populus plants, Zn treatment strongly altered the leaf morphology and ultrastructure, inducing a significant thickening of the leaf lamina and spongy tissue [85]. In high concentrations, $\mathrm{Zn}$ induces chlorosis and necrosis, and reduces the aerial biomass in Populus species and Brassica rapa $[85,86]$.

Metal-induced stress reduces the rate of photosynthesis and induces reactive oxygen species (ROS) generation [76], which can lead to lipid peroxidation, protein impairment, enzyme inactivation, and DNA damage [77]. Although $\mathrm{Zn}$ is a non-redox metal, it generates ROS by indirect mechanisms. Its mechanisms are based on either the stimulation of ROS-producing enzymes, such as Nicotinamide Adenine Dinucleotide Phosphate Hydrogen (NADPH) oxidases, displacing essential cations from specific enzyme-binding sites, or the inhibition of enzyme activities [87]. Under Zn stress, mitogen-activated protein kinase (MAPK) activation results from the activation of oxidative stress in 
Oryza sativa L. MAPKs are serine/threonine kinases involved in the phosphorylation of a number of transcriptional factors [87]. Reactive oxygen species cause the death of plants by damaging membrane lipids, proteins, pigments, and nucleic acids $[77,88]$.

Proline accumulation is a widespread process among higher plants in response to zinc and other heavy metal stress. At $1 \mathrm{mM}$ of $\mathrm{Zn}$, a rise of proline was mainly observed in the roots of Triticum aestivum [70]. The same results were also recorded for Solanum lycopersicum tissues with an increase in Zn concentrations (0.05, 0.1, 0.15, and $0.2 \mathrm{mM}$ ) [89], and in Vigna unguiculata seedlings treated with 0.25 and $0.5 \mathrm{mM}$ of $\mathrm{Zn}$ [60]. It is assumed that proline increases the plant's tolerance to heavy metals through several mechanisms, such as osmoregulation, stabilization of protein synthesis, and enzyme protection against denaturation [88]. Proline accumulation has been shown to alleviate metal-induced oxidative stress by scavenging toxic ROS [90]. Tripathi and Gaur [88] suggested that proline accumulation is somehow triggered by ROS, which allows their direct detoxification without the intervention of antioxidant enzymes. To cope with this damage, cells produce antioxidant enzymes like superoxide dismutase (SOD), peroxidase (POD), catalase (CAT), ascorbate peroxidase (APX), and guaiacol peroxidase [70]. SOD plays an important role in detoxification processes by catalyzing the conversion of free $\mathrm{O}_{2}{ }^{-}$to $\mathrm{O}_{2}$ and $\mathrm{H}_{2} \mathrm{O}_{2}$ and is associated with stress situations, including zinc stress [79]. In Myracrodruon urundeuva, increased SOD activity was seen in Zn-treated plants [91]. In Plantago major, CAT enzyme activity increased significantly under Zn stress in the shoot and root [92].

\section{Zn Hyperaccumulator Plants}

Despite the toxic effect of heavy metals in plant development, some plant species have developed different strategies to overcome high metal concentrations, which are usually considered phytotoxic in soils. Metal accumulation in the shoots is a naturally selected process that represents one of these strategies $[93,94]$. Some plants are known for their ability to accumulate abnormally high concentrations of metals, such as $\mathrm{Zn}$, nickel $(\mathrm{Ni})$, manganese $(\mathrm{Mn})$, or lead $(\mathrm{Pb})$, in their aboveground parts to more than $1 \%$ of their dry weight $[95,96]$. These plants are called hyperaccumulators. About 450 plant species have been identified as hyperaccumulators for different heavy metals. Metals are translocated to the shoots and accumulated in the aboveground organs, mainly the leaves. Zn hyperaccumulator plants can accumulate more than 10,000 ppm dry weight in their aerial parts when growing in a natural habitat. For example, Arabidopsis halleri and Noccaea caerulescens have the ability to accumulate extremely high concentrations of $\mathrm{Zn}$ of up to 13,620 and 43,710 ppm of $\mathrm{Zn}$, respectively, when growing in $\mathrm{Zn}$-enriched metalliferous soils [97]. Addititonally, Dichapetalum subsp. sumatranum and D. subsp. pilosum are strong Zn hyperaccumulators, which can accumulate over 15,660 and 26,360 ppm of $\mathrm{Zn}$ in their leaves, respectively [98]. Other researchers have proposed that plants with $\mathrm{Zn}$ accumulation levels greater than 3000 ppm should be considered as hyperaccumulators. For example, Thlaspi ochroleucum, which can accumulate up to $6300 \mathrm{ppm}$ of $\mathrm{Zn}$, is considered as a physiologically abnormal and hyperaccumulator species [99]. Accordingly, other researchers classify plants based on the shoot:root ratios of metal concentrations and admit that plants with a shoot:root ratio $>1$ are generally $\mathrm{Zn}$ hyperaccumulators while non-accumulator plants' Zn shoot:root ratios is less than 1 [100]. The literature describes several plants as species that tolerate an environment rich in $\mathrm{Zn}$. $28 \mathrm{Zn}$-hyperaccumulating plant species have been described to date (Table 1). Most of these species belong to the Brassicaceae family, but other families are also represented, such as Caryophyllaceae and Dichapetalaceae [14,101]. 
Table 1. List of Zn hyperaccumulator plants.

\begin{tabular}{|c|c|c|c|}
\hline Species & Family & Hyperaccumulation Criteria & References \\
\hline Justicia procumbens & Acanthaceae & $>10,000$ ppm in LDW & [101] \\
\hline Arabidopsis helleri & Brassicaceaa & $>10,000$ ppm in LDW & [97] \\
\hline Noccaea caerulescens & Brassicaceaa & $>10,000$ ppm in LDW & [97] \\
\hline Arabis paniculata & Brassicaceae & $>10,000$ ppm in LDW & [102] \\
\hline Noccaea eburneosa & Brassicaceae & Zn concentration in shoot \%DW 1.05 & [103] \\
\hline Noccaea alpestre & Brassicaceae & $>10,000$ ppm in LDW & [103] \\
\hline Noccaea bulbosum Spruner & Brassicaceae & Zn concentration in shoot \%DW 1.05 & [103] \\
\hline Noccaea calaminare & Brassicaceae & $>10,000$ ppm in LDW & [103] \\
\hline Noccaea limosellifolium & Brassicaceae & Zn concentration in shoot \%DW 1.10 & [103] \\
\hline Noccaea praecox & Brassicaceae & $>10,000 \mathrm{ppm}$ in LDW & [103] \\
\hline Arabis gemmifera & Brassicaceae & $>10,000 \mathrm{ppm}$ in LDW & [101] \\
\hline Noccaeagoesingense & Brassicaceae & $>10,000$ ppm in LDW & [101] \\
\hline Noccaea brachypetalum & Brassicaceae & Zn concentration in shoot \%DW 1.53 & [101] \\
\hline Noccaea cepaeifolium subsp Rotundifolium, & Brassicaceae & Zn concentration in shoot $\% \mathrm{DW} 2.10$ & [101] \\
\hline Noccaea stenopterum & Brassicaceae & $>10,000$ ppm in LDW & [101] \\
\hline Noccaea tatrense & Brassicaceae & $>10,000$ ppm in LDW & [101] \\
\hline Minuartia verna & Caryophyllaceae & Zn concentration in shoot $\% \mathrm{DW} 1.14$ & [101] \\
\hline Polycarpaea synandra & Caryophyllaceae & $>3000$ ppm (6960 ppm DW) & [101] \\
\hline Sedum alfredii & Crassulaceae & shoot: root ratio $>1$ & [101] \\
\hline Sedum plumbizincicola & Crassulaceae & $>10,000$ ppm in LDW & [101] \\
\hline Dichapetalum geloniodes subsp.sumatranum & Dichapetalaceae & $>10,000$ ppm in LDW & [101] \\
\hline Dichapetalum gelonioides & Dichapetalaceae & $>10,000 \mathrm{ppm}$ in LDW & [101] \\
\hline Anthyllis vulneraria & Fabaceae & $>10,000$ ppm in LDW & [101] \\
\hline Haumaniastrum katanngense & Lamiaceae & Zn concentration in shoot $\%$ DW 1.98 & [103] \\
\hline Ficus parietalis & Moraceae & - & [101] \\
\hline Potentilla griffithii & Rosaceae & $>10,000$ ppm in LDW & [104] \\
\hline Rinorea longiracemosa & Violaceae & - & [101] \\
\hline Viola calaminaria & Violaceae & $>10,000$ ppm in LDW & [103] \\
\hline
\end{tabular}

LDW: Leaf Dry Weight; DW: Dry Weight.

\subsection{Morphological Response of Zn Hyperaccumulator Plants}

Several researchers have reported morphological changes that affect Zn-accumulating plants due to the presence of $\mathrm{Zn}$ in the environment. Gallego et al. [105] noticed that in the presence of medium concentrations of $\mathrm{Zn}$, Noccaea caerulescens developed better than control plants (grown in normal conditions). Excess $\mathrm{Zn}$ affected the growth of Noccaea caerulescens plants less. However, there was a significant decrease in the root dry weight at $0.8 \mathrm{mM}$ [106]. Roots can also respond via changes in the growth pattern and morphology. Studies on S. alfredii demonstrated that the root length, surface area, and volume visibly increased under $0.5 \mathrm{mM}$ of $\mathrm{Zn} \mathrm{[107].} \mathrm{Changes} \mathrm{in} \mathrm{the} \mathrm{root} \mathrm{morphology} \mathrm{of}$ $S$. alfredii were also observed, such as an increase in the diameter class distribution of specific root lengths and specific root surface areas [107]. Many Zn hyperaccumulators (except for trees) have been described with small shallow $(<0.5 \mathrm{~m})$ root systems and a high proportion of fine roots that contribute to trace element accumulation [108]. Belouchrani et al. [109] indicated that Zn hyperaccumulation increased the leaf number in Brassica napus, changed the root system architecture, and increased lateral root formation after exposure to $\mathrm{Zn}$ ions. 


\subsection{Physiological and Biochemical Responses in Zn Hyperaccumulator Plants}

$\mathrm{Zn}$-tolerant plants are characterized by their ability to grow in a Zn-rich medium without showing signs of chlorosis, necrosis, or strong growth inhibition [19]. The maintenance of biomass production even at the highest $\mathrm{Zn}$ doses $(0.5 \mathrm{mM})$ indicates the $\mathrm{Zn}$ tolerance of Sedum alfredii [107]. In Noccaea caerulescens, tolerance to $\mathrm{Zn}$ is shown by the stability of PSII compared to the control sensitive plants [110].

Hyperaccumulator plants produce root exudates to improve the metal bioavailability. Organic materials, including low molecular weight compounds (amino acids, organic acids, sugars, phenolic compounds) and compounds of high molecular weight (polysaccharides and proteins), mobilize $\mathrm{Zn}$ from the soil by acidification and/or chelate secretion [111]. The hyperaccumulator Sedum alfredii secretes dissolved organic matter in exudate and has a higher $\mathrm{Zn}$ complexation and extraction capacity [112]. Moreover, S. alfredii mainly uses these mechanisms to activate metal in the rhizosphere [112]. Furthermore, Dessureault-Rompré et al. [113] suggested that mobile metal-dissolved soil organic matter complexes play an important role in the rapid replacement of available $\mathrm{Zn}$ pools in the rhizosphere of hyperaccumulating N. caerulescens. Zn might also stimulate citrate production in N. caerulescens roots [95].

In addition, Tsednee et al. [39] and Leitenmaier and Küpper [27] reported that the secretion of nicotianamine (NA) by the root improves A. halleri's tolerance to $\mathrm{Zn}$. A. halleri secretes more NA than A. thaliana (non-tolerant). In A. halleri, NA synthesis increases when plants are exposed to excess $\mathrm{Zn}$. $\mathrm{Xu}$ et al. [114] reported that excess $\mathrm{Zn}$ induces an accumulation of nitric oxide (NO) in the roots of the $\mathrm{Zn}$ accumulator Solanum nigrum. $\mathrm{Zn}$ induces the generation of $\mathrm{ROS}$, including hydrogen peroxide $\left(\mathrm{H}_{2} \mathrm{O}_{2}\right)$ and superoxide radicals. To alleviate the damage caused by ROS production, hyperaccumulator species, like S. alfredii and N. caerulescens, produce high concentrations of ascorbic acid and glutathione and antioxidant enzymes, such as catalase, peroxidase, and ascorbate peroxidase $[115,116]$.

Metabolite synthesis is also one of the strategies used by hyperaccumulator plants to prevent toxicity from heavy metals [117]. Glutathione (GSH) amounts increased in a metallicolous population of S. alfredii in comparison with the non-metallicolous one and might serve as an antioxidant or metal chelator involved in Zn detoxification [118]. Instead of GSH, phytochelatins (PCs), small cystein-rich peptides, do not have a specific role in the binding of $\mathrm{Zn}$ in hyperaccumulator plant species [95]. As reported in a metallicolous population of Sedum alfredii, PCs and cysteine (Cys) were not detected in any tissue [118]. It was previously revealed that an important PC's synthesis in heavy metal-exposed plants would cost a considerable amount of energy required for the sulphate reduction [117]. Furthermore, metallothioneins (MTs) are reported to be involved in Zn hyperaccumulation. The Zn hyperaccumulator $N$. caerulescens displays constitutively higher MT expression than $A$. thaliana. Moreover, NcMT1 and NcMT2 showed overexpression patterns in N. caerulescens organs and in response to $\mathrm{Zn}$ exposure, which suggests a possible role of MTs in the tZn hyperaccumulation process [119].

\section{Molecular Mechanisms of Zn Hyperaccumulation}

After bioactivation in the rhizosphere, $\mathrm{Zn}$ is then absorbed by the roots through mass flow and diffusion mechanisms. In plants, $\mathrm{Zn}$ can follow two different pathways to reach the xylem: (i) Symplastic route: The cytoplasm of neighboring cells in the root tissues is connected by cytoplasmic bridges (plasmodesmata) in the cell wall, forming a symplastic continuum without membrane barriers. Cytoplasmic $\mathrm{Zn}$ then follows this path to the pericycle without spending energy [100]; and (ii) the apoplastic route, where $\mathrm{Zn}$ moves across the cell wall and intercellular spaces. $\mathrm{Zn}$ is then blocked in the endodermis by lamellae deposition in the casparian strip [100]. An unusual root feature (cells of the perendodermis with irregularly thickened tangential walls with deposition of lignin) was observed in the hyperaccumulator $N$. caerulescens compared to the non-hyperaccumulator $N$. arvense [120]. van de Mortel et al. [121] suggested that the plant uses lignin depositions to control metal influx or to prevent excess metal efflux from the central stele, providing the plant with the capacity to maintain a lower metal concentration in the cortex and then busting the metal uptake from the soil. When reaching the endodermis level, $\mathrm{Zn}$ must move in a symplastic way using transporters. In this way, $\mathrm{Zn}$ ions flux to the stele can be reduced through vacuolar retention [122]. Nevertheless, less Zn vacuolar sequestration 
in the root is an important mechanism for $\mathrm{Zn}$ hyperaccumulation. It was found that N. caerulescens stored approximately 2.5 times less $\mathrm{Zn}$ in the root cell vacuoles compared to the sensitive species N. arvense [122]. Additionally, the main sites of $\mathrm{Zn}$ accumulation in P. griffithii were the apoplast, particularly in the cell walls [123].

In general, the molecular mechanisms involved in metal hyperaccumulation are essentially derived from the mechanisms involved in metal homeostasis in plants. Several studies showed that the same genes involved in metal homeostasis are differentially expressed in hyperaccumulators compared to related non-accumulator species as a result of gene duplication and/or changes in promoter regulation $[124,125]$. In the case of $\mathrm{Zn}$, genes involved in the hyperaccumulation strategy were mostly identified in both A. halleri and N. caerulescens [126,127].

\subsection{Zinc Uptake}

The rhizosphere is the first area of contact between metal and plants. In the soil, Zn occurs preferably in a crystalline form in iron-magnesium minerals, such as sulfide (ZnS). Zn is largely adsorbed in changeable forms, mainly as $\mathrm{Zn}^{2+}, \mathrm{ZnOH}^{+}$, and $\mathrm{ZnCl}^{+}$, onto clay surfaces and organic matter [11]. Roots generally absorb zinc as $\mathrm{Zn}^{2+}$ ions except at high $\mathrm{pH}$, where it is absorbed as $\mathrm{ZnOH}$ [128].

Many transporters belonging to the zinc-regulated transporter/iron-regulated transporter-like proteins (ZRT-IRT-like protein or ZIP family) and involved in Zn radial transport to the stele in roots have been identified. In N. caerulescens, NcZNT1, a major contributor to Zn transport across the endodermal cell, was isolated [121]. Constitutive overexpression of NcZNT1, a plasma membrane-located metal transporter, in $A$. thaliana enhanced the tolerance to excess Zn exposure and increased the accumulation of Zn compared to wild-type plants [129]. Furthermore, NcZNT 2 and 5, respectively orthologs of $A$. thaliana iron-regulated transporter 3 (IRT3) and ZIP5, are involved in Zn transport in the roots [121,130]. Additionally, IRT3 was detected in the plasma membrane of $A$. halleri cells in the roots after exposure to $\mathrm{Zn}[129,131,132]$. Interestingly, high levels of IRT3 expression were found in the roots of Zn-hyperaccumulating species, such as A. halleri and N. caerulescens [11,131]. Other studies conducted by Shanmugan et al. [133] showed that IRT1 located in the plasma membrane is involved in Zn transport. Lin et al. [129] also observed a subcellular location of this transporter in the plasma membrane, which confirms its importance in the passage of these ions to the cellular cytoplasm. ZIP19 and ZIP23 expression was significantly induced in A. halleri and N. caerulescens roots in the presence of $\mathrm{Zn} \mathrm{[129].} \mathrm{In} \mathrm{A.} \mathrm{thaliana,} \mathrm{high} \mathrm{levels} \mathrm{of} \mathrm{ZIP19} \mathrm{and} \mathrm{ZIP23} \mathrm{expression} \mathrm{were} \mathrm{observed} \mathrm{in} \mathrm{a} \mathrm{Zn} \mathrm{deficient}$ culture medium [134], which suggests that the upregulation of these two genes in A. halleri and $N$. caerulescens might be correlated with a low Zn content in the rhizosphere due to the high activity of heavy metal ATPase 4 (HMA4) (involved in $\mathrm{Zn}$ translocation from the xylem to aboveground parts) [124,129] (Figure 1). 


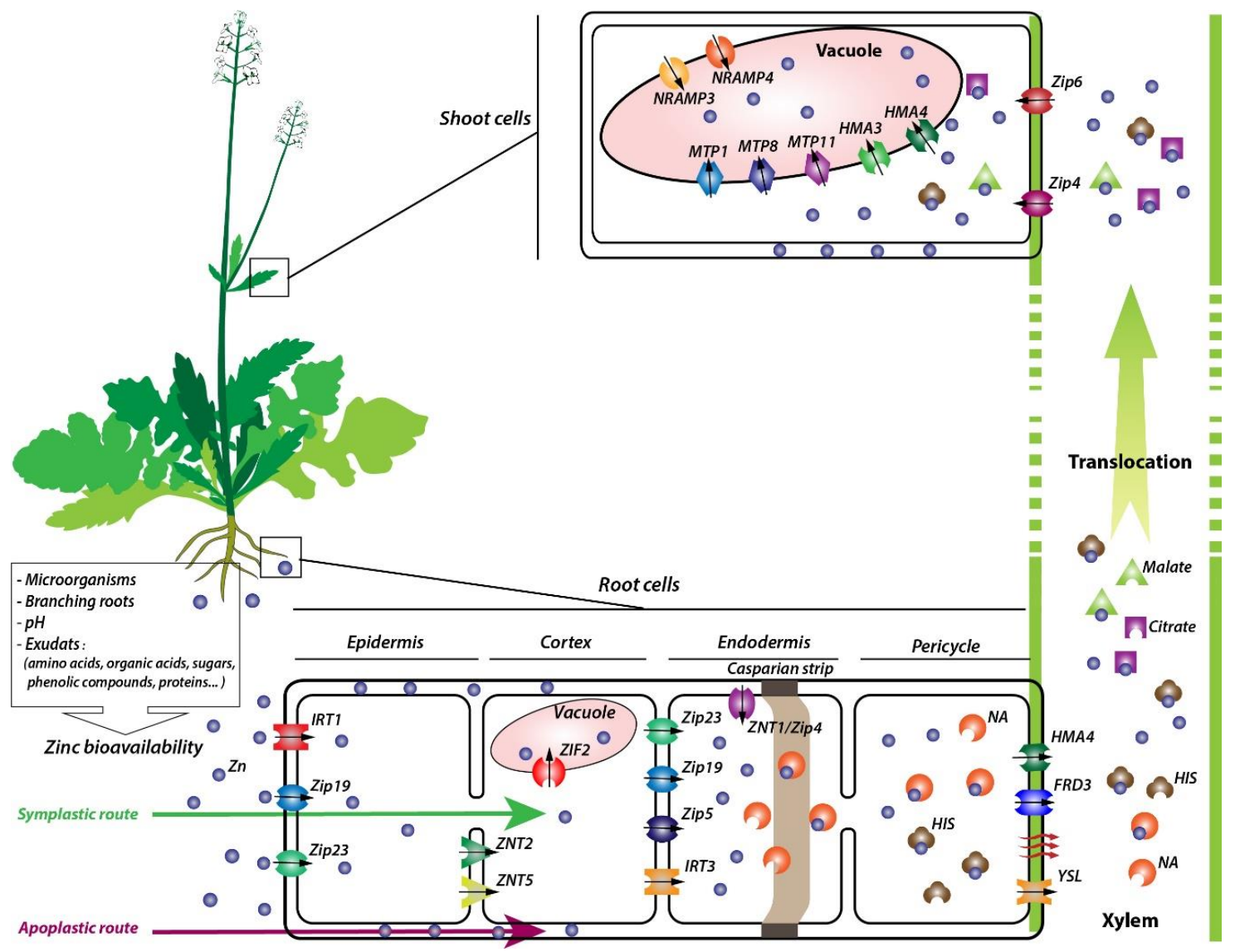

Figure 1. A model of the mechanisms that occur in hyperaccumulation plants upon exposure to zinc (Zn): Zn ion uptake, chelation, transport, and sequestration. Zn bioavailability can be influenced by several factors, such as microorganisms, branching roots, $\mathrm{pH}$, and exudates. Once adsorbed by the roots, $\mathrm{Zn}$ can be absorbed by an apoplastic route: A passive diffusion through cells, or by a symplastic route via transporters. Within the latter path, $\mathrm{Zn}$ absorption by epidermis cells is mainly promoted by IRT1, ZIP19, and ZIP23. To reach the cortex, Zn can be directly diffused or by means of ZNT2 and ZNT5. Then, Zn can either be stocked in vacuoles (promoted by ZIF2) or transported to the endodermis through the following transporters: ZIP23, ZIP19, ZIP5, and IRT3. Zn following the apoplastic route is stopped by the casparian strip, and then enters the endodermis via ZNT1/ZIP4. At this level, Zn can be chelated by nicotianamine (NA) or directly diffused to pericycle cells where a part can also be associated to histidine (His). The unchelated Zn can reach the xylem through direct diffusion or via YSL, ferric reductase defective 3 (FRD3,) and HMA4. Zn then crosses the xylem as a Zn-free form or coupled with His, citrate, or malate. To enter the leaf cells, Zn can passively penetrate in chelated forms or as the Zn-free form via ZIP4 and ZIP6 proteins. It is then sequestrated inside the vacuole through MTP1 (metal tolerance proteins 1), MTP8, MTP11, NRAMP3, NRAMP4, HMA3, and HMA4 transporters, or blocked in the cell wall.

In addition to the ZIP family, another gene is described to have a role in zinc uptake. In Arabidopsis, Remy et al. [135] showed that ZIF2 (zinc-induced facilitator 2) is primarily localized at the tonoplast of root cortical cells and mediates $\mathrm{Zn}$ uptake (Figure 1).

\subsection{Zn Xylem Loading and Transport Processes}

Once excess $\mathrm{Zn}$ reaches the endoderm of hyperaccumulator plants, $\mathrm{Zn}$ is loaded with root vessels to xylem vessels [11]. In the xylem parenchyma, $\mathrm{Zn}$ will be chelated with low molecular weight ligands to prevent its retention by surrounding cell walls [11,136]. For instance, Zn translocation in A. halleri is accompanied with strong nicotianamine (NA) secretion, a non-proteinogenic amino acid 
that, once bound to Zn, prevents its rapid absorption $[137,138]$. The nicotianamine synthase (NAS) catalyzes NA synthesis from three molecules of S-adenosyl-methionine [139]. NAS1, NAS2, and NAS3 genes expression revealed a difference between hyperaccumulator and non-hyperaccumulator plants. In addition, expression studies have showed that in N. caerulescens, NA synthesis is governed by NAS2 while in A. halleri, it is controlled by NAS2 and NAS3 [121,140]. Inhibition of NA synthesis in the root induces a decrease in $\mathrm{Zn}$ translocation. After an analysis of xylem exudates, Cornu et al. [141] suggested that organic acids, such as malate and citrate, are the main ligands in xylem, while NA controls the loading rate of xylem only. For histidine (His), even if its specific mechanism of action is unclear, the supply of exogenous histidine contributes to the transport of $\mathrm{Zn}$ and increases the xylem loading process [142]. Milner and Kochian [143] found that $\mathrm{Zn}$ was complexed with His in the root but becomes free hydrated $\mathrm{Zn}^{2+}$ in the xylem whose small amount is bound with organic acids (Figure 1).

$\mathrm{Zn}$ translocation from the roots to the shoots involves the action of proteins belonging to the heavy metal ATPase "HMA" family. In A. halleri, heavy metal ATPase 4 (HMA4) and 2 (HMA2) act as a key component contributing to $\mathrm{Zn}$ hyperaccumulation and hypertolerance [144-146]. With a plasma membrane localization in the root pericycle cells, they promote $\mathrm{Zn}^{2+}$ efflux from these cells and are associated with its loading in the root xylem [11,147]. Transcriptional-level analysis in hyperaccumulator plants revealed a strong induction of these genes. HMA4 expression was 4 to 10-fold higher in roots and at least 30-fold higher in shoots of H. halleri compared to A. thaliana [131]. The increased expression of HMA4 is a result of tandem triplication and cis-regulatory changes that can activate the promoters of all three HMA4 copies [145]. Some genes from the ZIP family, likely ZIP4 and IRT3, are also involved in root-to-shoot translocation. It has previously been shown that the overexpression of AtIRT3 in A. thaliana increased Zn accumulation in the shoots, suggesting a potential involvement of this gene in $\mathrm{Zn}$ loading for long-distance transport [148] (Figure 1).

Other genes involved in Zn transfer are those of the yellow stripe-like (YSL) family. YSL transporters have been implicated in xylem loading and unloading of Zn [149]. YSL proteins are involved in $\mathrm{Mn}, \mathrm{Zn}, \mathrm{Cu}, \mathrm{Ni}, \mathrm{Cd}$, as well as Fe transport. They mainly mediate the cellular uptake of metals that are complexed to non-proteinogenic amino acids [150]. Similar to YSL, FRD3 (ferric reductase defective 3), a MATE (multidrug and toxin efflux) transporter, has been described as an essential regulator of $\mathrm{Zn}$ excess [151]. FRD3 expression was exclusively detected in the pericycle and cells surrounding the vascular tissues [152]. This protein could be of primary importance in the distribution of metals between cells [136] (Figure 1). FRD3 is essential for Fe/Zn translocation via the xylem $[153,154]$.

In A. thaliana, there is another important efflux transporter: Plant cadmium resistance 2 (PCR2). PCR2 functions as a Zn efflux transporter, which contributes to $\mathrm{Zn}$ translocation and detoxification [155]. However, its implication in Zn hyperaccumulation is not understood.

After $\mathrm{Zn}$ loading in the xylem using different transporters from three major families HMA, ZIP, and YLS, Zn reaches the leaves, where it is mainly bound to organic acids, such as malate and citrate, and then sequestered in vacuoles.

\subsection{Zinc Sequestration in the Aboveground Part of the Plants}

After been chelated (with NA, His, etc.) in the roots and translocated towards the xylem, $\mathrm{Zn}$ reaches the shoot, where it is stored bound to chelators (organic acids). A small portion of $\mathrm{Zn}$ can also be found as free ions or bound to the cell wall or histidine [143]. In N. caerulescens shoots, concentrations of malate, oxalate, succinate, and citrate are detected only after high $\mathrm{Zn}$ exposure [95]. $38 \%, 9 \%, 16 \%$, and $12 \%$ of the total $\mathrm{Zn}$ was associated with citrate, oxalate, His, and the cell wall, respectively, while $26 \%$ remained as free $\mathrm{Zn}^{2+}$ ions in the shoots of N. caerulescens [95]. Afterward, chelated $\mathrm{Zn}$ is stored in different cells/tissues depending on the plant species. For example, A. halleri promotes the accumulation of $\mathrm{Zn}$ at the base of trichomes and also in mesophyll cells [156] whereas $N$. caerulescens stores metals in the leaves' epidermis [156]. In Sedum alfredii, Zn is at the level of the epidermis of the stems and leaves [157]. In contrast, mesophyll cells accumulate small amounts of Zn 
in hyperaccumulator plants as an adaptation strategy [124,158]. Zn accumulation includes efficient metal import and loading in the vacuoles along with a regulated redistribution from this compartment. The potential actors involved in these mechanisms comprise members of several transporter families. Yang et al. [159] identified the SaZIP4 gene as a key $\mathrm{Zn}$ transporter in the $\mathrm{Zn}$ hyperaccumulation process of Sedum alfredii. A subcellular localization analysis showed that ZIP4 is located in the plasma membrane and is involved in $\mathrm{Zn}$ uptake in the shoots but also in the roots. Another member of the same family, ZIP6, located in the plasma membrane of the shoot, promotes Zn uptake as its expression was predominant in the shoots of A. halleri $[100,160]$ (Figure 1).

Once in the cytosol, $\mathrm{Zn}$ is stored in the vacuoles as a strategy of hyperaccumulator species to prevent $\mathrm{Zn}$ damage of vital organelles, such as chloroplast. Sitko et al. [161] showed that metallicolous populations of $A$. halleri were characterized by a high chlorophyll content compared to non-tolerant plants. This finding can be explained by the inhibition of $\mathrm{Zn}$ accumulation in chloroplasts in this species [161]. It was confirmed that HMA1, a member of the P1B-type ATPase superfamily, was identified and localized on the chloroplast envelope in A. thaliana [162] (Figure 1). Furthermore, Arabidopsis HMA1 knockout plants were more sensitive to $\mathrm{Zn}$ and accumulated a high amount of $\mathrm{Zn}$ in the chloroplast compared to wild-type plants [162]. These authors showed that HMA1 is associated with $\mathrm{Zn}^{2+}$ transport from the chloroplasts to the cytoplasm under conditions of high levels of zinc, avoiding damage to the organelle. However, the implication of HMA1 in Zn transport in hyperaccumulator species has not been confirmed yet. We can thus suggest the possible involvement of HMA1 in the inhibition of $\mathrm{Zn}$ accumulation in the chloroplasts of hyperaccumulator species.

It was confirmed that members of the MTP/ABCC (metal tolerance proteins/ATP binding cassette $\mathrm{C})$, belonging to the superfamily of the cation diffusion facilitator (CDF) protein, are involved in $\mathrm{Zn}$ loading in the vacuoles [163]. In the leaves, the vacuolar protein MTP1 plays a key role in Zn sequestration and detoxification. It was reported that MTP1 contributes to Zn accumulation in the shoots of $A$. halleri [163] Likewise, in $N$ goesingense, TgMTP1 protein is accumulated in high levels in the vacuolar membrane in the shoot, which confirms its implication in $\mathrm{Zn}$ tolerance and accumulation enhancement in this species [164]. Next to MTP1, upregulation by high Zn of MTP8 and MTP11 was also confirmed in the shoots of the $Z n$ hyperaccumulators $N$. caerulescens and A. halleri [126]. Like MTP1, ZNT5 is also an important player in the sequestration of Zn into the epidermal storage cells $[106,165]$ (Figure 1).

Recently, HMA4, previously described as a Zn xylem transporter, and HMA3, another member of the P1B-type ATPase superfamily, were studied regarding their implication in $\mathrm{Zn} / \mathrm{Cd}$ sequestration in shoots [156]. The regulation of both HMA3 and HMA4 was analyzed at the tissue and cellular level in the Zn hyperaccumulators A. halleri and N. caerulescens. In A. halleri, the highest expression of HMA3 and HMA4 was found in the mesophyll, while in N. caerulescens, HMA3, and HMA4 were significantly upregulated in the bundle sheath of the vein. This can be explained by the final storage sites; the epidermis for N. caerulescens and mesophyll for A. halleri [156]. HMA3, located in the vacuolar membrane, participates in vacuolar sequestration of $\mathrm{Zn}$ [156]. In addition to these genes, four other genes belonging to the NRAMP (natural resistance-associated macrophage protein) family, NRAMP1, NRAMP3, NRAMP4, and NRAMP5, have been described to be involved in Zn sequestration in the vacuole of leaf cells. These transporters use the transmembrane proton gradient to facilitate the transport of a broad range of divalent cations toward the cytosol [166]. In N. caerulescens, NRAMP1 and NRAMP5 were found to be highly expressed in the shoots specifically $[167,168]$. High expression of the NRAMP3 gene was observed in the leaves of the Zn hyperaccumulating A. halleri [168]. NcNRAMP4 was implicated in $\mathrm{Zn}$ hypertolerance with localization at the vacuolar membrane [169], but the precise role NcNRAMP3 is yet to be determined. 


\section{Genetic Basis of Zn Hyperaccumulation}

Most research on $\mathrm{Zn}$ hyperaccumulators has focused on the physiological and molecular mechanisms of $\mathrm{Zn}$ uptake, transport, and sequestration, but relatively little is known regarding the genomic variation and genetic evolution of the $\mathrm{Zn}$ hyperaccumulation characteristic.

It is known that interspecific heavy metal tolerance can occur differently. For example, A. halleri is geographically distributed in Europe and eastern Asia and has been divided into metallicolous, non-metallicolous, and hybrid populations. Comparative studies have shown that metallicolous populations accumulate more $\mathrm{Zn}$ than non-metallicolous populations [94]. These observations were contradicted by those of Frérot et al. and Stein et al. [144,170]. It was suggested that the hyperaccumulation characteristic in A. halleri is due to population evolution rather than a new mutation [171]. This same population variation was also observed in N. caerulescens [172]. Meanwhile, Nowak et al. [173] described of a reduction in the hyperaccumulation capacities between populations. There are no known cases of major genetic polymorphisms in which some members of a species are capable of hyperaccumulation and others are not. Whereas, Lin and Aarts [174] described a similar $\mathrm{Zn}$ absorbance between the two populations of Sedum alfredii. Similarly, biomass changes depend on the population, for example, an excess of $\mathrm{Zn}$ in the medium induces the growth of $S$. alfredii from metallicolous sites whereas for non-metallicolous populations, it causes a decrease in the biomass accompanied with several toxic symptoms [159].

The random amplified polymorphic DNA (RAPD) method was used to compare the genomic variation of Sedum hyperaccumulating ecotype (HE) and non-hyperaccumulating ecotype (NHE), and revealed that the $\mathrm{Zn} / \mathrm{Cd}$ hyperaccumulation trait was related to SH-containing compounds [175]. Recently, Yang et al. [176] identified molecular markers single nucleotide polymorphisms (SNPs) and simple sequence repeats (SSRs) of S. alfredii, which constitutes an important resource for genome mapping to identify hyperaccumulation and hypertolerance traits. From this approach, 18 divergent orthologous genes involved in the transcription and translation processes, protein metabolism process, $\mathrm{Ca}^{2+}$ signaling pathway, stress response process, and signal transduction process were identified in HE [176]. Schvartzman et al. [94] examined the mechanisms underlying the intraspecific variation in two geographically distant metallicolous populations of $A$. halleri. The transcriptomic analysis revealed that the geographic origin represented a major source of variation in the accumulation properties and gene expression profiles. This study suggested that the two metallicolous populations developed different strategies to adapt to an increasing $\mathrm{Zn}$ content in the soil through $\mathrm{Zn}$ crosstalk modifications [94].

The revelation of a genetic basis of hyperaccumulation traits can be achieved by cross-referencing between tolerant and sensitive species. A study performed in $N$. caerulescens showed the presence of three quantitative trait loci (QTLs) related to Zn accumulation [177]. QTL mapping of zinc tolerance was used to analyze the first-generation backcross progeny from $A$. halleri ssp. and its non-tolerant relative A. lyrata ssp. petraea [178]. The authors identified three QTLs and showed that in all these QTLs, $\mathrm{Zn}$ tolerance was improved by $A$. halleri alleles. This result was explained by the positive selection of higher $\mathrm{Zn}$ tolerance in this species [178]. Whether it is an adaptation or a reduction in this capacity, differences between populations remain a very important point to study in order to understand the evolutionary steps that lead to zinc tolerance and/or accumulation.

\section{Conclusions}

The understanding of $\mathrm{Zn}$ uptake and hyperaccumulation mechanisms in plants has been considerably advanced in recent years. Some plants have developed a range of physiological adaptation strategies to tolerate and hyperaccumulate $\mathrm{Zn}$ in their aboveground parts. Many genes belonging to different families (HMA, ZIP, YSL, MTP, etc.) have been identified as being involved in Zn tolerance and hyperaccumulation, and transcriptomic analysis of contrasting populations has clarified the evolutionary mechanisms of the $\mathrm{Zn}$ hyperaccumulation characteristic. 
All these advances are of high relevance for understanding the physiological processes of $\mathrm{Zn}$ transfer from the soil to the plant's tissues and cellular compartments. Hence, the application of Zn hyperaccumulator plants for phytoremediation and clean-up of Zn-contaminated soils has become a reality. Phytoremediation is a green, eco-friendly, and low-cost technology recognized as an effective method for the remediation of metal-contaminated soils [179]. However, exploitation of hyperaccumulation for soil decontamination is limited due to the low biomass and slow growth of hyperaccumulator plants and the low bioavailability of $\mathrm{Zn}$ in the soil $[111,180]$. Rhizosphere microbes, especially the PGPR, endophytic bacteria, and mycorrhizae, and the application of fertilizers and exogenous chelators can mend $\mathrm{Zn}$ mobility and bioavailability and effectively assist in phytoremediation [181]. Moreover, recent advances in genetic engineering and genome editing tools, like clustered regularly interspaced palindromic repeats (CRISPR) strategies [182], will allow a better understanding of the molecular mechanisms involved in $\mathrm{Zn}$ uptake, transport, and accumulation in plants. This will lead to improvements in Zn hyperaccumulation and can open new possibilities for soil decontamination.

Author Contributions: Writing-Original Draft Preparation, H.B. and M.F.; Writing-Review and Editing, D.B., Z.-E.A.T., A.G., N.B., A.S. and M.F.; Supervision, A.S. and M.F.; Project Administration, A.S. and M.F.; Funding Acquisition, A.S. and M.F. All authors have read and agreed the proof version to be published.

Funding: The APC was funded by "Institute of Research for Development- France IRD: JEAI-PhytoMet 2018-2020."

Acknowledgments: Published with the support of "IRD: JEAI-PhytoMet 2018-2020; LMI «AMIR» 2020-2025" and Programme Prioritaire de recherche PPR- Ministère de l'Enseignement Supérieur, de la Recherche Scientifique et de la Formation des Cadres.

Conflicts of Interest: The authors have declared that no competing interests exist.

\section{References}

1. Marschner, H. Marschner's Mineral Nutrition of Higher Plants; Academic Press: Cambridge, MA, USA, 2011.

2. Lehmann, A.; Veresoglou, S.D.; Leifheit, E.F.; Rillig, M.C. Arbuscular mycorrhizal influence on zinc nutrition in crop plants-a meta-analysis. Soil Biol. Biochem. 2014, 69, 123-131. [CrossRef]

3. Zhang, Y.; Hu, C.-X.; Tan, Q.-L.; Zheng, C.-S.; Gui, H.-P.; Zeng, W.-N.; Sun, X.-C.; Zhao, X.-H. Plant nutrition status, yield and quality of satsuma mandarin (Citrus unshiu Marc.) under soil application of Fe-EDDHA and combination with zinc and manganese in calcareous soil. Sci. Hortic. 2014, 174, 46-53. [CrossRef]

4. Castillo-González, J.; Ojeda-Barrios, D.; Hernández-Rodríguez, A.; González-Franco, A.C.; Robles-Hernández, L.; López-Ochoa, G.R. Zinc Metalloenzymes in Plants. Interciencia 2018, 43, 242-248.

5. Mousavi, S.R. Zinc in crop production and interaction with phosphorus. Aust. J. Basic and Appl. Sci. 2011, 5, 1503-1509.

6. Cakmak, I.; Öztürk, L.; Karanlik, S.; Marschner, H.; Ekiz, H. Zinc-efficient wild grasses enhance release of phytosiderophores under zinc deficiency. J. Plant Nutr. 1996, 19, 551-563. [CrossRef]

7. Cambier, P.; Schvartz, C.; Van Oort, F. Contaminations Métalliques des Agrosystèmes et Écosystèmes Péri-Industriels; Editions Quae: Paris, France, 2009.

8. Duplay, J.; Semhi, K.; Errais, E.; Imfeld, G.; Babcsanyi, I.; Perrone, T. Copper, zinc, lead and cadmium bioavailability and retention in vineyard soils (Rouffach, France): The impact of cultural practices. Geoderma 2014, 230, 318-328. [CrossRef]

9. Kwon, M.J.; Boyanov, M.I.; Yang, J.-S.; Lee, S.; Hwang, Y.H.; Lee, J.Y.; Mishra, B.; Kemner, K.M. Transformation of zinc-concentrate in surface and subsurface environments: Implications for assessing zinc mobility/toxicity and choosing an optimal remediation strategy. Environ. Pollut. 2017, 226, 346-355. [CrossRef]

10. Wyszkowski, M.; Modrzewska, B. Acidity and sorption properties of Zinc-contaminated soil following the application of neutralising substances. J. Ecol. Eng. 2016, 17. [CrossRef]

11. Moreira, A.; Moraes, L.A.; dos Reis, A.R. The molecular genetics of zinc uptake and utilization efficiency in crop plants. In Plant Micronutrient Use Efficiency; Elsevier: Amsterdam, The Netherlands, 2018; pp. 87-108. 
12. Tiecher, T.L.; Ceretta, C.A.; Tiecher, T.; Ferreira, P.A.; Nicoloso, F.T.; Soriani, H.H.; Rossato, L.V.; Mimmo, T.; Cesco, S.; Lourenzi, C.R. Effects of zinc addition to a copper-contaminated vineyard soil on sorption of $\mathrm{Zn}$ by soil and plant physiological responses. Ecotoxicol. Environ. Saf. 2016, 129, 109-119. [CrossRef]

13. Prasad, M. Essentiality of zinc for human health and sustainable development. In Trace Elements as Contaminants and Nutrients: Consequences in Ecosystems and Human Health; Prasad, M.N.V., Ed.; John Wiley \& Sons Inc.: Hoboken, NJ, USA, 2008; pp. 183-216.

14. Clemens, S. How metal hyperaccumulating plants can advance Zn biofortification. Plant Soil 2017, 411, 111-120. [CrossRef]

15. Krämer, U. Metal hyperaccumulation in plants. Annu. Rev. Plant Biol. 2010, 61, 517-534. [CrossRef] [PubMed]

16. Wuana, R.A.; Okieimen, F.E. Heavy metals in contaminated soils: A review of sources, chemistry, risks and best available strategies for remediation. Isrn Ecol. 2011, 2011. [CrossRef]

17. Noulas, C.; Tziouvalekas, M.; Karyotis, T. Zinc in soils, water and food crops. J. Trace Elem. Med. Biol. 2018, 49, 252-260. [CrossRef] [PubMed]

18. Liu, G.; Xing, J.; Ma, S.; He, Y.; Fu, H.; Gao, Y.; Wang, Y.; Wang, Y. Effects of erosion angle on erosion properties of Fe-B alloy in flowing liquid zinc. Metall. Mater. Trans. A 2015, 46, 1900-1907. [CrossRef]

19. Mateos-Naranjo, E.; Castellanos, E.M.; Perez-Martin, A. Zinc tolerance and accumulation in the halophytic species Juncus acutus. Environ. Exp. Bot. 2014, 100, 114-121. [CrossRef]

20. Dong, C.-D.; Chen, C.-F.; Chen, C.-W. Contamination of zinc in sediments at river mouths and channel in northern Kaohsiung Harbor, Taiwan. Int. J. Environ. Sci. Dev. 2012, 3, 517. [CrossRef]

21. Chahal, D.; Sharma, B.; Singh, P. Distribution of forms of zinc and their association with soil properties and uptake in different soil orders in semi-arid soils of Punjab, India. Commun. Soil Sci. Plant Anal. 2005, 36, 2857-2874. [CrossRef]

22. Sadeghzadeh, B.; Rengel, Z. Zinc in soils and crop nutrition. In The Molecular and Physiological Basis of Nutrient Use Efficiency in Crops; Hawkesford, M.J., Barraclough, P., Eds.; Wiley-Blackwell: Hoboken, NJ, USA, 2011; pp. 335-375.

23. González-Alcaraz, M.N.; van Gestel, C.A. Climate change effects on enchytraeid performance in metal-polluted soils explained from changes in metal bioavailability and bioaccumulation. Environ. Res. 2015, 142, 177-184. [CrossRef]

24. Adamczyk-Szabela, D.; Markiewicz, J.; Wolf, W.M. Heavy metal uptake by herbs. IV. Influence of soil pH on the content of heavy metals in Valeriana officinalis L. Water Air Soil Pollut. 2015, 226, 106. [CrossRef]

25. Pinto, E.; Aguiar, A.A.; Ferreira, I.M. Influence of soil chemistry and plant physiology in the phytoremediation of Cu, Mn, and Zn. Crit. Rev. Plant Sci. 2014, 33, 351-373. [CrossRef]

26. Imran, M.; Arshad, M.; Khalid, A.; Kanwal, S.; Crowley, D.E. Perspectives of rhizosphere microflora for improving Zn bioavailability and acquisition by higher plants. Int. J. Agric. Biol. 2014, 16, 653-662.

27. Leitenmaier, B.; Küpper, H. Compartmentation and complexation of metals in hyperaccumulator plants. Front. Plant Sci. 2013, 4, 374. [CrossRef] [PubMed]

28. DalCorso, G. Heavy metal toxicity in plants. In Plants and Heavy Metals; Springer: Berlin, Germany, 2012; pp. 1-25.

29. Misra, V.; Tiwari, A.; Shukla, B.; Seth, C.S. Effects of soil amendments on the bioavailability of heavy metals from zinc mine tailings. Environ. Monit. Assess. 2009, 155, 467-475. [CrossRef] [PubMed]

30. Cao, X.; Wahbi, A.; Ma, L.; Li, B.; Yang, Y. Immobilization of $\mathrm{Zn}, \mathrm{Cu}$, and $\mathrm{Pb}$ in contaminated soils using phosphate rock and phosphoric acid. J. Hazard. Mater. 2009, 164, 555-564. [CrossRef]

31. Hafeez, B.; Khanif, Y.; Saleem, M. Role of zinc in plant nutrition-a review. J. Exp. Agric. Int. 2013, 3, 374-391. [CrossRef]

32. Cakmak, I. Enrichment of fertilizers with zinc: An excellent investment for humanity and crop production in India. J. Trace Elem. Med. Biol. 2009, 23, 281-289. [CrossRef]

33. Clemente, R.; Hartley, W.; Riby, P.; Dickinson, N.M.; Lepp, N.W. Trace element mobility in a contaminated soil two years after field-amendment with a greenwaste compost mulch. Environ. Pollut. 2010, 158, 1644-1651. [CrossRef]

34. Chen, Y.; Cui, J.; Tian, X.; Zhao, A.; Li, M.; Wang, S.; Li, X.; Jia, Z.; Liu, K. Effect of straw amendment on soil $\mathrm{Zn}$ availability and ageing of exogenous water-soluble $\mathrm{Zn}$ applied to calcareous soil. PLoS ONE 2017, 12, e0169776. [CrossRef] 
35. Seshadri, B.; Bolan, N.; Naidu, R. Rhizosphere-induced heavy metal (loid) transformation in relation to bioavailability and remediation. J. Soil Sci. Plant Nutr. 2015, 15, 524-548. [CrossRef]

36. Hou, Y.; Liu, X.; Zhang, X.; Chen, X.; Tao, K. Effects of key components of S. triqueter root exudates on fractions and bioavailability of pyrene-lead co-contaminated soils. Int. J. Environ. Sci. Technol. 2016, 13, 887-896. [CrossRef]

37. Chen, Y.-T.; Wang, Y.; Yeh, K.-C. Role of root exudates in metal acquisition and tolerance. Curr. Opin. Plant Biol. 2017, 39, 66-72. [CrossRef] [PubMed]

38. Medas, D.; De Giudici, G.; Casu, M.A.; Musu, E.; Gianoncelli, A.; Iadecola, A.; Meneghini, C.; Tamburini, E.; Sprocati, A.R.; Turnau, K. Microscopic processes ruling the bioavailability of $\mathrm{Zn}$ to roots of Euphorbia pithyusa L. pioneer plant. Environ. Sci. Technol. 2015, 49, 1400-1408. [CrossRef] [PubMed]

39. Tsednee, M.; Yang, S.-C.; Lee, D.-C.; Yeh, K.-C. Root-secreted nicotianamine from Arabidopsis halleri facilitates zinc hypertolerance by regulating zinc bioavailability. Plant Physiol. 2014, 166, 839-852. [CrossRef] [PubMed]

40. Degryse, F.; Verma, V.; Smolders, E. Mobilization of $\mathrm{Cu}$ and $\mathrm{Zn}$ by root exudates of dicotyledonous plants in resin-buffered solutions and in soil. Plant soil 2008, 306, 69-84. [CrossRef]

41. Wei-Hong, X.; Huai, L.; Qi-Fu, M.; Xiong, Z.-T. Root exudates, rhizosphere Zn fractions, and Zn accumulation of ryegrass at different soil Zn levels. Pedosphere 2007, 17, 389-396.

42. Versieren, L.; Smets, E.; De Schamphelaere, K.; Blust, R.; Smolders, E. Mixture toxicity of copper and zinc to barley at low level effects can be described by the Biotic Ligand Model. Plant Soil 2014, 381, 131-142. [CrossRef]

43. Hrynkiewicz, K.; Dabrowska, G.; Baum, C.; Niedojadlo, K.; Leinweber, P. Interactive and single effects of ectomycorrhiza formation and Bacillus cereus on metallothionein MT1 expression and phytoextraction of Cd and Zn by willows. Water Air Soil Pollut. 2012, 223, 957-968. [CrossRef]

44. Ramesh, A.; Sharma, S.K.; Sharma, M.P.; Yadav, N.; Joshi, O.P. Inoculation of zinc solubilizing Bacillus aryabhattai strains for improved growth, mobilization and biofortification of zinc in soybean and wheat cultivated in Vertisols of central India. Appl. Soil Ecol. 2014, 73, 87-96. [CrossRef]

45. Vogel-Mikuš, K.; Pongrac, P.; Kump, P.; Nečemer, M.; Regvar, M. Colonisation of a Zn, Cd and Pb hyperaccumulator Thlaspi praecox Wulfen with indigenous arbuscular mycorrhizal fungal mixture induces changes in heavy metal and nutrient uptake. Environ. Pollut. 2006, 139, 362-371. [CrossRef]

46. McCall, K.A.; Huang, C.-c.; Fierke, C.A. Function and mechanism of zinc metalloenzymes. J. Nutr. 2000, 130, 1437S-1446S. [CrossRef]

47. Robson, A.D. Zinc in Soils and Plants, Proceedings of the International Symposium on 'Zinc in Soils and Plants', held at the University of Western Australia, Perth, Australia, 27-28 September 1993; Springer Science \& Business Media: Berlin, Germany, 2012; Volume 55.

48. Kisko, M.; Bouain, N.; Rouached, A.; Choudhary, S.P.; Rouached, H. Molecular mechanisms of phosphate and zinc signalling crosstalk in plants: Phosphate and zinc loading into root xylem in Arabidopsis. Environ. Exp. Bot. 2015, 114, 57-64. [CrossRef]

49. Samreen, T.; Shah, H.U.; Ullah, S.; Javid, M. Zinc effect on growth rate, chlorophyll, protein and mineral contents of hydroponically grown mungbeans plant (Vigna radiata). Arab. J. Chem. 2017, 10, S1802-S1807. [CrossRef]

50. Pessarakli, M. Handbook of Photosynthesis; CRC Press: Boca Raton, FL, USA, 2016.

51. Jain, A.; Sinilal, B.; Dhandapani, G.; Meagher, R.B.; Sahi, S.V. Effects of deficiency and excess of zinc on morphophysiological traits and spatiotemporal regulation of zinc-responsive genes reveal incidence of cross talk between micro-and macronutrients. Environ. Sci. Technol. 2013, 47, 5327-5335. [CrossRef] [PubMed]

52. Sturikova, H.; Krystofova, O.; Huska, D.; Adam, V. Zinc, zinc nanoparticles and plants. J. Hazard. Mater. 2018, 349, 101-110. [CrossRef]

53. Jain, R.; Srivastava, S.; Solomon, S.; Shrivastava, A.; Chandra, A. Impact of excess zinc on growth parameters, cell division, nutrient accumulation, photosynthetic pigments and oxidative stress of sugarcane (Saccharum spp.). Acta Physiol. Plant. 2010, 32, 979-986. [CrossRef]

54. Reis, S.; Pavia, I.; Carvalho, A.; Moutinho-Pereira, J.; Correia, C.; Lima-Brito, J. Seed priming with iron and zinc in bread wheat: Effects in germination, mitosis and grain yield. Protoplasma 2018, 255, 1179-1194. [CrossRef]

55. Gokak, I.; Taranath, T. Seed germination and growth responses of Macrotyloma uniflorum (Lam.) Verdc. exposed to Zinc and Zinc nanoparticles. Int. J. Environ. Sci. 2015, 5, 840. 
56. Ivanov, Y.V.; Kartashov, A.V.; Ivanova, A.I.; Savochkin, Y.V.; Kuznetsov, V.V. Effects of zinc on Scots pine (Pinus sylvestris L.) seedlings grown in hydroculture. Plant Physiol. Biochem. 2016, 102, 1-9. [CrossRef]

57. Zhi, Y.; Deng, Z.; Luo, M.; Ding, W.; Hu, Y.; Deng, J.; Li, Y.; Zhao, Y.; Zhang, X.; Wu, W. Influence of Heavy Metals on Seed Germination and Early Seedling Growth in Eruca sativa Mill. Am. J. Plant Sci. 2015, 6, 582. [CrossRef]

58. Marichali, A.; Dallali, S.; Ouerghemmi, S.; Sebei, H.; Hosni, K. Germination, morpho-physiological and biochemical responses of coriander (Coriandrum sativum L.) to zinc excess. Ind. Crops Prod. 2014, 55, 248-257. [CrossRef]

59. Marichali, A.; Dallali, S.; Ouerghemmi, S.; Sebei, H.; Casabianca, H.; Hosni, K. Responses of Nigella sativa L. to Zinc excess: Focus on germination, growth, yield and yield components, lipid and terpene metabolism, and total phenolics and antioxidant activities. J. Agric. Food Chem. 2016, 64, 1664-1675. [CrossRef] [PubMed]

60. Basha, S.A.; Selvaraju, M. Toxic effect of Zinc on growth and nutrient accumulation of cow pea (Vigna unguiculata L.). Int. Lett. Nat. Sci. 2015, 43. [CrossRef]

61. Nanda, R.; Agrawal, V. Elucidation of zinc and copper induced oxidative stress, DNA damage and activation of defence system during seed germination in Cassia angustifolia Vahl. Environ. Exp. Bot. 2016, 125, 31-41. [CrossRef]

62. Gupta, S.; Meena, M.; Datta, S. Effect of selected heavy metals (Lead AND Zinc) on seedling growth of Soybean Glycine Max (L.) MERR'. J. Pharm. Pharm. Sci. 2016, 8, 302-305.

63. Bae, J.; Benoit, D.L.; Watson, A.K. Effect of heavy metals on seed germination and seedling growth of common ragweed and roadside ground cover legumes. Environ. Pollut. 2016, 213, 112-118. [CrossRef]

64. Disante, K.B.; Cortina, J.; Vilagrosa, A.; Fuentes, D.; Hernández, E.I.; Ljung, K. Alleviation of Zn toxicity by low water availability. Physiol. Plant. 2014, 150, 412-424. [CrossRef]

65. Bochicchio, R.; Sofo, A.; Terzano, R.; Gattullo, C.E.; Amato, M.; Scopa, A. Root architecture and morphometric analysis of Arabidopsis thaliana grown in $\mathrm{Cd} / \mathrm{Cu} / \mathrm{Zn}$-gradient agar dishes: A new screening technique for studying plant response to metals. Plant Physiol. Biochem. 2015, 91, 20-27. [CrossRef]

66. Emamverdian, A.; Ding, Y.; Mokhberdoran, F.; Xie, Y. Heavy metal stress and some mechanisms of plant defense response. Sci. World J. 2015, 2015. [CrossRef]

67. Küpper, H.; Andresen, E. Mechanisms of metal toxicity in plants. Metallomics 2016, 8, 269-285. [CrossRef]

68. Mustafa, G.; Komatsu, S. Toxicity of heavy metals and metal-containing nanoparticles on plants. Biochim. Biophys. Acta BBA Proteins Proteom. 2016, 1864, 932-944. [CrossRef]

69. Kranner, I.; Colville, L. Metals and seeds: Biochemical and molecular implications and their significance for seed germination. Environ. Exp. Bot. 2011, 72, 93-105. [CrossRef]

70. Li, X.; Yang, Y.; Jia, L.; Chen, H.; Wei, X. Zinc-induced oxidative damage, antioxidant enzyme response and proline metabolism in roots and leaves of wheat plants. Ecotoxicol. Environ. Saf. 2013, 89, 150-157. [CrossRef] [PubMed]

71. Luo, Z.-B.; He, X.-J.; Chen, L.; Tang, L.; Gao, S.; Chen, F. Effects of zinc on growth and antioxidant responses in Jatropha curcas seedlings. Int. J. Agric. Biol. 2010, 12, 119-124.

72. Subba, P.; Mukhopadhyay, M.; Mahato, S.K.; Bhutia, K.D.; Mondal, T.K.; Ghosh, S.K. Zinc stress induces physiological, ultra-structural and biochemical changes in mandarin orange (Citrus reticulata Blanco) seedlings. Physiol. Mol. Biol. Plants 2014, 20, 461-473. [CrossRef]

73. Liu, D.; Chen, J.; Mahmood, Q.; Li, S.; Wu, J.; Ye, Z.; Peng, D.; Yan, W.; Lu, K. Effect of Zn toxicity on root morphology, ultrastructure, and the ability to accumulate $\mathrm{Zn}$ in Moso bamboo (Phyllostachys pubescens). Environ. Sci. Pollut. Res. 2014, 21, 13615-13624. [CrossRef]

74. Scheid, D.L.; De Marco, R.; Grolli, A.L.; Da Silva, R.F.; Da Ros, C.O.; Andreazza, R. Growth, tolerance and zinc accumulation in Senna multijuga and Erythrina crista-galli seedlings. Rev. Bras. Eng. Agríc. Ambient. 2017, 21, 465-470. [CrossRef]

75. Sagardoy, R.; Vázquez, S.; Florez-Sarasa, I.; Albacete, A.; Ribas-Carbó, M.; Flexas, J.; Abadía, J.; Morales, F. Stomatal and mesophyll conductances to $\mathrm{CO}_{2}$ are the main limitations to photosynthesis in sugar beet (Beta vulgaris) plants grown with excess zinc. New Phytol. 2010, 187, 145-158. [CrossRef]

76. Fernàndez, J.; Zacchini, M.; Fleck, I. Photosynthetic and growth responses of Populus clones Eridano and I-214 submitted to elevated Zn concentrations. J. Geochem. Exp. 2012, 123, 77-86. [CrossRef]

77. Miller, G.; Shulaev, V.; Mittler, R. Reactive oxygen signaling and abiotic stress. Physiol. Plant. 2008, 133, 481-489. [CrossRef] 
78. Anwaar, S.A.; Ali, S.; Ali, S.; Ishaque, W.; Farid, M.; Farooq, M.A.; Najeeb, U.; Abbas, F.; Sharif, M. Silicon (Si) alleviates cotton (Gossypium hirsutum $\mathrm{L}$.) from zinc $(\mathrm{Zn})$ toxicity stress by limiting $\mathrm{Zn}$ uptake and oxidative damage. Environ. Sci. Pollut. Res. 2015, 22, 3441-3450. [CrossRef]

79. Feigl, G.; Lehotai, N.; Molnár, Á.; Ördög, A.; Rodríguez-Ruiz, M.; Palma, J.M.; Corpas, F.J.; Erdei, L.; Kolbert, Z. Zinc induces distinct changes in the metabolism of reactive oxygen and nitrogen species (ROS and RNS) in the roots of two Brassica species with different sensitivity to zinc stress. Ann. Bot. 2015, 116, 613-625. [CrossRef] [PubMed]

80. Khan, M.I.R.; Khan, N.A. Ethylene reverses photosynthetic inhibition by nickel and zinc in mustard through changes in PS II activity, photosynthetic nitrogen use efficiency, and antioxidant metabolism. Protoplasma 2014, 251, 1007-1019. [CrossRef] [PubMed]

81. Vijayarengan, P.; Mahalakshmi, G. Zinc toxicity in tomato plants. World Appl. Sci. J. 2013, 24, 649-653.

82. Cambrollé, J.; Mancilla-Leytón, J.; Muñoz-Vallés, S.; Luque, T.; Figueroa, M. Zinc tolerance and accumulation in the salt-marsh shrub Halimione portulacoides. Chemosphere 2012, 86, 867-874. [CrossRef] [PubMed]

83. Monnet, F.; Vaillant, N.; Vernay, P.; Coudret, A.; Sallanon, H.; Hitmi, A. Relationship between PSII activity, $\mathrm{CO} 2$ fixation, and $\mathrm{Zn}, \mathrm{Mn}$ and Mg contents of Lolium perenne under zinc stress. J. Plant Physiol. 2001, 158, 1137-1144. [CrossRef]

84. Azzarello, E.; Pandolfi, C.; Giordano, C.; Rossi, M.; Mugnai, S.; Mancuso, S. Ultramorphological and physiological modifications induced by high zinc levels in Paulownia tomentosa. Environ. Exp. Bot. 2012, 81, 11-17. [CrossRef]

85. Todeschini, V.; Lingua, G.; D’agostino, G.; Carniato, F.; Roccotiello, E.; Berta, G. Effects of high zinc concentration on poplar leaves: A morphological and biochemical study. Environ. Exp. Bot. 2011, 71, 50-56. [CrossRef]

86. Blasco, B.; Graham, N.S.; Broadley, M.R. Antioxidant response and carboxylate metabolism in Brassica rapa exposed to different external Zn, Ca, and Mg supply. J. Plant Physiol. 2015, 176, 16-24. [CrossRef]

87. Hossain, M.A.; Piyatida, P.; da Silva, J.A.T.; Fujita, M. Molecular mechanism of heavy metal toxicity and tolerance in plants: Central role of glutathione in detoxification of reactive oxygen species and methylglyoxal and in heavy metal chelation. J. Bot. 2012, 2012. [CrossRef]

88. Tripathi, B.N.; Gaur, J. Relationship between copper-and zinc-induced oxidative stress and proline accumulation in Scenedesmus sp. Planta 2004, 219, 397-404. [CrossRef]

89. Al Khateeb, W.; Al-Qwasemeh, H. Cadmium, copper and zinc toxicity effects on growth, proline content and genetic stability of Solanum nigrum L., a crop wild relative for tomato; comparative study. Physiol. Mol. Biol. Plants 2014, 20, 31-39. [CrossRef] [PubMed]

90. Michael, P.I.; Krishnaswamy, M. The effect of zinc stress combined with high irradiance stress on membrane damage and antioxidative response in bean seedlings. Environ. Exp. Bot. 2011, 74, 171-177. [CrossRef]

91. Gomes, M.; Duarte, D.; Carneiro, M.; Barreto, L.; Carvalho, M.; Soares, A.; Guilherme, L.; Garcia, Q. Zinc tolerance modulation in Myracrodruon urundeuva plants. Plant Physiol. Biochem. 2013, 67, 1-6. [CrossRef] [PubMed]

92. Branch, D.; Damghan, I.; Branch, Q.; Qaemshahr, I. Protective role of exogenous nitric oxide against zinc toxicity in Plantago major L. Appl. Ecol. Environ. Res. 2017, 15, 511-524.

93. Babst-Kostecka, A.; Schat, H.; Saumitou-Laprade, P.; Grodzińska, K.; Bourceaux, A.; Pauwels, M.; Frérot, H. Evolutionary dynamics of quantitative variation in an adaptive trait at the regional scale: The case of zinc hyperaccumulation in Arabidopsis halleri. Mol. Ecol. 2018, 27, 3257-3273. [CrossRef]

94. Schvartzman, M.S.; Corso, M.; Fataftah, N.; Scheepers, M.; Nouet, C.; Bosman, B.; Carnol, M.; Motte, P.; Verbruggen, N.; Hanikenne, M. Adaptation to high zinc depends on distinct mechanisms in metallicolous populations of Arabidopsis halleri. New Phytol. 2018, 218, 269-282. [CrossRef]

95. Broadley, M.R.; White, P.J.; Hammond, J.P.; Zelko, I.; Lux, A. Zinc in plants. New Phytol. 2007, 173, 677-702. [CrossRef]

96. Marques, A.P.; Rangel, A.O.; Castro, P.M. Remediation of heavy metal contaminated soils: Phytoremediation as a potentially promising clean-up technology. Crit. Rev. Environ. Sci. Technol. 2009, 39, 622-654. [CrossRef]

97. Peer, W.A.; Mahmoudian, M.; Freeman, J.L.; Lahner, B.; Richards, E.L.; Reeves, R.D.; Murphy, A.S.; Salt, D.E. Assessment of plants from the Brassicaceae family as genetic models for the study of nickel and zinc hyperaccumulation. New Phytol. 2006, 172, 248-260. [CrossRef] 
98. Baker, A.; Proctor, J.; Van Balgooy, M.; Reeves, R. Hyperaccumulation of nickel by the flora of the ultramafics of Palawan, Republic of the Philippines. In The Vegetation of Ultramafic (Serpentine) Soils'; Baker, A.J.M., Proctor, J., Reeves, R.D., Eds.; Intercept Ltd: hampshire, UK, 1992; pp. 291-304.

99. Van der Ent, A.; Baker, A.J.; Reeves, R.D.; Pollard, A.J.; Schat, H. Hyperaccumulators of metal and metalloid trace elements: Facts and fiction. Plant Soil 2013, 362,319-334. [CrossRef]

100. Gupta, N.; Ram, H.; Kumar, B. Mechanism of Zinc absorption in plants: Uptake, transport, translocation and accumulation. Rev. Environ. Sci. Bio Technol. 2016, 15, 89-109. [CrossRef]

101. Reeves, R.D.; Baker, A.J.; Jaffré, T.; Erskine, P.D.; Echevarria, G.; van der Ent, A. A global database for plants that hyperaccumulate metal and metalloid trace elements. New Phytol. 2018, 218, 407-411. [CrossRef] [PubMed]

102. Tang, Y.-T.; Qiu, R.-L.; Zeng, X.-W.; Ying, R.-R.; Yu, F.-M.; Zhou, X.-Y. Lead, zinc, cadmium hyperaccumulation and growth stimulation in Arabis paniculata Franch. Environ. Exp. Bot. 2009, 66, 126-134. [CrossRef]

103. Brooks, R.R. Plants that hyperaccumulate heavy metals. In Plants and the Chemical Elements: Biochemistry, Uptake, Tolerance and Toxicity; Farago, M.E., Ed.; John Wiley \& Sons: Hoboken, NJ, USA, 1994; pp. 87-105.

104. Qiu, R.-L.; Thangavel, P.; Hu, P.-J.; Senthilkumar, P.; Ying, R.-R.; Tang, Y.-T. Interaction of cadmium and zinc on accumulation and sub-cellular distribution in leaves of hyperaccumulator Potentilla griffithii. J. Hazard. Mater. 2011, 186, 1425-1430. [CrossRef] [PubMed]

105. Gallego, B.; Martos, S.; Cabot, C.; Barceló, J.; Poschenrieder, C. Zinc hyperaccumulation substitutes for defense failures beyond salicylate and jasmonate signaling pathways of Alternaria brassicicola attack in Noccaea caerulescens. Physiol. Plant. 2017, 159, 401-415. [CrossRef]

106. Kozhevnikova, A.D.; Seregin, I.; Gosti, F.; Schat, H. Zinc accumulation and distribution over tissues in Noccaea caerulescens in nature and in hydroponics: A comparison. Plant Soil 2017, 411, 5-16. [CrossRef]

107. Li, T.; Yang, X.; Lu, L.; Islam, E.; He, Z. Effects of zinc and cadmium interactions on root morphology and metal translocation in a hyperaccumulating species under hydroponic conditions. J. Hazard. Mater. 2009, 169, 734-741. [CrossRef]

108. Alford, É.R.; Pilon-Smits, E.A.; Paschke, M.W. Metallophytes-A view from the rhizosphere. Plant Soil 2010, 337, 33-50. [CrossRef]

109. Belouchrani, A.S.; Mameri, N.; Abdi, N.; Grib, H.; Lounici, H.; Drouiche, N. Phytoremediation of soil contaminated with Zn using Canola (Brassica napus L). Ecol. Eng. 2016, 95, 43-49. [CrossRef]

110. Bayçu, G.; Gevrek-Kürüm, N.; Moustaka, J.; Csatári, I.; Rognes, S.E.; Moustakas, M. Cadmium-zinc accumulation and photosystem II responses of Noccaea caerulescens to Cd and Zn exposure. Environ. Sci. Pollut. Res. 2017, 24, 2840-2850. [CrossRef]

111. Zhao, F.; Hamon, R.; McLaughlin, M.J. Root exudates of the hyperaccumulator Thlaspi caerulescens do not enhance metal mobilization. New Phytol. 2001, 151, 613-620. [CrossRef]

112. Li, T.; Di, Z.; Yang, X.; Sparks, D.L. Effects of dissolved organic matter from the rhizosphere of the hyperaccumulator Sedum alfredii on sorption of zinc and cadmium by different soils. J. Hazard. Mater. 2011, 192, 1616-1622. [CrossRef] [PubMed]

113. Dessureault-Rompré, J.; Luster, J.; Schulin, R.; Tercier-Waeber, M.-L.; Nowack, B. Decrease of labile Zn and Cd in the rhizosphere of hyperaccumulating Thlaspi caerulescens with time. Environ. Pollut. 2010, 158, 1955-1962. [CrossRef] [PubMed]

114. Xu, J.; Yin, H.; Li, Y.; Liu, X. Nitric oxide is associated with long-term zinc tolerance in Solanum nigrum. Plant Physiol. 2010, 154, 1319-1334. [CrossRef]

115. Jin, X.F.; Yang, X.E.; Islam, E.; Liu, D.; Mahmood, Q.; Li, H.; Li, J. Ultrastructural changes, zinc hyperaccumulation and its relation with antioxidants in two ecotypes of Sedum alfredii Hance. Plant Physiol. Biochem. 2008, 46, 997-1006. [CrossRef]

116. Wójcik, M.; Skórzyńska-Polit, E.; Tukiendorf, A. Organic acids accumulation and antioxidant enzyme activities in Thlaspi caerulescens under Zn and Cd stress. Plant Growth Regul. 2006, 48, 145-155. [CrossRef]

117. Steffens, J. The heavy metal-binding peptides of plants. Annu. Rev. Plant Biol. 1990, 41, 553-575. [CrossRef]

118. Sun, Q.; Ye, Z.; Wang, X.; Wong, M.H. Increase of glutathione in mine population of Sedum alfredii: A Zn hyperaccumulator and $\mathrm{Pb}$ accumulator. Phytochemistry 2005, 66, 2549-2556. [CrossRef]

119. Roosens, N.H.; Leplae, R.; Bernard, C.; Verbruggen, N. Variations in plant metallothioneins: The heavy metal hyperaccumulator Thlaspi caerulescens as a study case. Planta 2005, 222, 716. [CrossRef] 
120. Zelko, I.; Lux, A.; Czibula, K. Difference in the root structure of hyperaccumulator Thlaspi caerulescens and non-hyperaccumulator Thlaspi arvense. Int. J. Environ. Pollut. 2008, 33, 123-132. [CrossRef]

121. Van de Mortel, J.E.; Villanueva, L.A.; Schat, H.; Kwekkeboom, J.; Coughlan, S.; Moerland, P.D.; van Themaat, E.V.L.; Koornneef, M.; Aarts, M.G. Large expression differences in genes for iron and zinc homeostasis, stress response, and lignin biosynthesis distinguish roots of Arabidopsis thaliana and the related metal hyperaccumulator Thlaspi caerulescens. Plant Physiol. 2006, 142, 1127-1147. [CrossRef] [PubMed]

122. Lasat, M.M.; Baker, A.J.; Kochian, L.V. Altered Zn compartmentation in the root symplasm and stimulated $\mathrm{Zn}$ absorption into the leaf as mechanisms involved in $\mathrm{Zn}$ hyperaccumulation in Thlaspi caerulescens. Plant Physiol. 1998, 118, 875-883. [CrossRef] [PubMed]

123. Hu, P.-J.; Qiu, R.-L.; Senthilkumar, P.; Jiang, D.; Chen, Z.-W.; Tang, Y.-T.; Liu, F.-J. Tolerance, accumulation and distribution of zinc and cadmium in hyperaccumulator Potentilla griffithii. Environ. Exp. Bot. 2009, 66, 317-325. [CrossRef]

124. Merlot, S.; de la Torre, V.S.G.; Hanikenne, M. Physiology and molecular biology of trace element hyperaccumulation. In Agromining: Farming for Metals; Springer: Berlin, Germany, 2018; pp. 93-116.

125. Shahzad, Z.; Gosti, F.; Frérot, H.; Lacombe, É.; Roosens, N.; Saumitou-Laprade, P.; Berthomieu, P. The five AhMTP1 zinc transporters undergo different evolutionary fates towards adaptive evolution to zinc tolerance in Arabidopsis halleri. PLoS Genet. 2010, 6, e100911. [CrossRef] [PubMed]

126. Hanikenne, M.; Nouet, C. Metal hyperaccumulation and hypertolerance: A model for plant evolutionary genomics. Curr. Opin. Plant Biol. 2011, 14, 252-259. [CrossRef]

127. Verbruggen, N.; Hermans, C.; Schat, H. Molecular mechanisms of metal hyperaccumulation in plants. New Phytol. 2009, 181, 759-776. [CrossRef]

128. Li, C. Absorption and Translocation of Zn Foliar Fertilisers. Master's Thesis, The University of Queensland, Brisbane, Australia, 2019.

129. Lin, Y.-F.; Hassan, Z.; Talukdar, S.; Schat, H.; Aarts, M.G. Expression of the ZNT1 zinc transporter from the metal hyperaccumulator Noccaea caerulescens confers enhanced zinc and cadmium tolerance and accumulation to Arabidopsis thaliana. PLoS ONE 2016, 11, e0149750. [CrossRef]

130. Fasani, E. Plants that hyperaccumulate heavy metals. In Plants and Heavy Metals; Springer: Berlin, Germany, 2012; pp. 55-74.

131. Talke, I.N.; Hanikenne, M.; Krämer, U. Zinc-dependent global transcriptional control, transcriptional deregulation, and higher gene copy number for genes in metal homeostasis of the hyperaccumulator Arabidopsis halleri. Plant Physiol. 2006, 142, 148-167. [CrossRef]

132. Caldelas, C.; Weiss, D.J. Zinc homeostasis and isotopic fractionation in plants: A review. Plant Soil 2017, 411, 17-46. [CrossRef]

133. Shanmugam, V.; Lo, J.-C.; Yeh, K.-C. Control of Zn uptake in Arabidopsis halleri: A balance between Zn and Fe. Front. Plant Sci. 2013, 4, 281. [CrossRef]

134. Humayan Kabir, A.; Swaraz, A.; Stangoulis, J. Zinc-deficiency resistance and biofortification in plants. J. Plant Nutr. Soil Sci. 2014, 177, 311-319. [CrossRef]

135. Remy, E.; Cabrito, T.R.; Batista, R.A.; Hussein, M.A.; Teixeira, M.C.; Athanasiadis, A.; Sá-Correia, I.; Duque, P. Intron retention in the $5^{\prime}$ UTR of the novel ZIF2 transporter enhances translation to promote zinc tolerance in Arabidopsis. PLoS Genet. 2014, 10, e1004375. [CrossRef] [PubMed]

136. Sinclair, S.A.; Krämer, U. The zinc homeostasis network of land plants. Biochim. Biophys. Acta BBA Mol. Cell Res. 2012, 1823, 1553-1567. [CrossRef] [PubMed]

137. Trampczynska, A.; Küpper, H.; Meyer-Klaucke, W.; Schmidt, H.; Clemens, S. Nicotianamine forms complexes with Zn (II) in vivo. Metallomics 2010, 2, 57-66. [CrossRef] [PubMed]

138. Clemens, S.; Aarts, M.G.; Thomine, S.; Verbruggen, N. Plant science: The key to preventing slow cadmium poisoning. Trends Plant Sci. 2013, 18, 92-99. [CrossRef] [PubMed]

139. Higuchi, K.; Nakanishi, H.; Suzuki, K.; Nishizawa, N.K.; Mori, S. Presence of nicotianamine synthase isozymes and their homologues in the root of graminaceous plants. Soil Sci. Plant Nutr. 1999, 45, 681-691. [CrossRef]

140. Hammond, J.P.; Bowen, H.C.; White, P.J.; Mills, V.; Pyke, K.A.; Baker, A.J.; Whiting, S.N.; May, S.T.; Broadley, M.R. A comparison of the Thlaspi caerulescens and Thlaspi arvense shoot transcriptomes. New Phytol. 2006, 170, 239-260. [CrossRef] 
141. Cornu, J.Y.; Deinlein, U.; Höreth, S.; Braun, M.; Schmidt, H.; Weber, M.; Persson, D.P.; Husted, S.; Schjoerring, J.K.; Clemens, S. Contrasting effects of nicotianamine synthase knockdown on zinc and nickel tolerance and accumulation in the zinc/cadmium hyperaccumulator Arabidopsis halleri. New Phytol. 2015, 206, 738-750. [CrossRef]

142. Kozhevnikova, A.D.; Seregin, I.V.; Erlikh, N.T.; Shevyreva, T.A.; Andreev, I.M.; Verweij, R.; Schat, H. Histidine-mediated xylem loading of zinc is a species-wide character in Noccaea caerulescens. New Phytol. 2014, 203, 508-519. [CrossRef]

143. Milner, M.J.; Kochian, L.V. Investigating heavy-metal hyperaccumulation using Thlaspi caerulescens as a model system. Ann. Bot. 2008, 102, 3-13. [CrossRef]

144. Frérot, H.; Hautekèete, N.-C.; Decombeix, I.; Bouchet, M.-H.; Créach, A.; Saumitou-Laprade, P.; Piquot, Y.; Pauwels, M. Habitat heterogeneity in the pseudometallophyte Arabidopsis halleri and its structuring effect on natural variation of zinc and cadmium hyperaccumulation. Plant Soil 2018, 423, 157-174. [CrossRef]

145. Hanikenne, M.; Talke, I.N.; Haydon, M.J.; Lanz, C.; Nolte, A.; Motte, P.; Kroymann, J.; Weigel, D.; Krämer, U. Evolution of metal hyperaccumulation required cis-regulatory changes and triplication of HMA4. Nature 2008, 453, 391-395. [CrossRef] [PubMed]

146. Verret, F.; Gravot, A.; Auroy, P.; Leonhardt, N.; David, P.; Nussaume, L.; Vavasseur, A.; Richaud, P. Overexpression of AtHMA4 enhances root-to-shoot translocation of zinc and cadmium and plant metal tolerance. FEBS Lett. 2004, 576, 306-312. [CrossRef] [PubMed]

147. Hussain, D.; Haydon, M.J.; Wang, Y.; Wong, E.; Sherson, S.M.; Young, J.; Camakaris, J.; Harper, J.F.; Cobbett, C.S. P-type ATPase heavy metal transporters with roles in essential zinc homeostasis in Arabidopsis. Plant Cell 2004, 16, 1327-1339. [CrossRef]

148. Lin, Y.F.; Liang, H.M.; Yang, S.Y.; Boch, A.; Clemens, S.; Chen, C.C.; Wu, J.F.; Huang, J.L.; Yeh, K.C. Arabidopsis IRT3 is a zinc-regulated and plasma membrane localized zinc/iron transporter. New Phytol. 2009, 182, 392-404. [CrossRef]

149. Curie, C.; Cassin, G.; Couch, D.; Divol, F.; Higuchi, K.; Le Jean, M.; Misson, J.; Schikora, A.; Czernic, P.; Mari, S. Metal movement within the plant: Contribution of nicotianamine and yellow stripe 1-like transporters. Ann. Bot. 2009, 103, 1-11. [CrossRef]

150. Socha, A.L.; Guerinot, M.L. Mn-euvering manganese: The role of transporter gene family members in manganese uptake and mobilization in plants. Front. Plant Sci. 2014, 5, 106. [CrossRef]

151. Pineau, C.; Loubet, S.; Lefoulon, C.; Chalies, C.; Fizames, C.; Lacombe, B.; Ferrand, M.; Loudet, O.; Berthomieu, P.; Richard, O. Natural variation at the FRD3 MATE transporter locus reveals cross-talk between Fe homeostasis and Zn tolerance in Arabidopsis thaliana. PLoS Genet. 2012, 8, e1003120. [CrossRef]

152. Kutrowska, A.; Szelag, M. Low-molecular weight organic acids and peptides involved in the long-distance transport of trace metals. Acta Physiol. Plant. 2014, 36, 1957-1968. [CrossRef]

153. Hassan, Z.; Aarts, M.G. Opportunities and feasibilities for biotechnological improvement of $\mathrm{Zn}, \mathrm{Cd}$ or Ni tolerance and accumulation in plants. Environ. Exp. Bot. 2011, 72, 53-63. [CrossRef]

154. Kumar, A.; Aery, N. Impact, metabolism, and toxicity of heavy metals in plants. In Plant Responses to Xenobiotics; Springer: Berlin, Germany, 2016; pp. 141-176.

155. Song, W.-Y.; Choi, K.S.; Geisler, M.; Park, J.; Vincenzetti, V.; Schellenberg, M.; Kim, S.H.; Lim, Y.P.; Noh, E.W.; Lee, Y. Arabidopsis PCR2 is a zinc exporter involved in both zinc extrusion and long-distance zinc transport. Plant Cell 2010, 22, 2237-2252. [CrossRef] [PubMed]

156. Mishra, S.; Mishra, A.; Küpper, H. Protein biochemistry and expression regulation of cadmium/zinc pumping ATPases in the hyperaccumulator plants Arabidopsis halleri and Noccaea caerulescens. Front. Plant Sci. 2017, 8, 835. [CrossRef] [PubMed]

157. Tian, S.K.; Lu, L.L.; Yang, X.E.; Labavitch, J.M.; Huang, Y.Y.; Brown, P. Stem and leaf sequestration of zinc at the cellular level in the hyperaccumulator Sedum alfredii. New Phytol. 2009, 182, 116-126. [CrossRef] [PubMed]

158. Cosio, C.; DeSantis, L.; Frey, B.; Diallo, S.; Keller, C. Distribution of cadmium in leaves of Thlaspi caerulescens. J. Exp. Bot. 2005, 56, 765-775. [CrossRef] [PubMed]

159. Yang, Q.; Ma, X.; Luo, S.; Gao, J.; Yang, X.; Feng, Y. SaZIP4, an uptake transporter of Zn/Cd hyperaccumulator Sedum alfredii Hance. Environ. Exp. Bot. 2018, 155, 107-117. [CrossRef] 
160. Becher, M.; Talke, I.N.; Krall, L.; Krämer, U. Cross-species microarray transcript profiling reveals high constitutive expression of metal homeostasis genes in shoots of the zinc hyperaccumulator Arabidopsis halleri. Plant J. 2004, 37, 251-268. [CrossRef]

161. Sitko, K.; Rusinowski, S.; Kalaji, H.M.; Szopiński, M.; Małkowski, E. Photosynthetic efficiency as bioindicator of environmental pressure in A. halleri. Plant Physiol. 2017, 175, 290-302. [CrossRef]

162. Kim, Y.Y.; Choi, H.; Segami, S.; Cho, H.T.; Martinoia, E.; Maeshima, M.; Lee, Y. AtHMA1 contributes to the detoxification of excess Zn (II) in Arabidopsis. Plant J. 2009, 58, 737-753. [CrossRef]

163. Dräger, D.B.; Desbrosses-Fonrouge, A.G.; Krach, C.; Chardonnens, A.N.; Meyer, R.C.; Saumitou-Laprade, P.; Krämer, U. Two genes encoding Arabidopsis halleri MTP1 metal transport proteins co-segregate with zinc tolerance and account for high MTP1 transcript levels. Plant J. 2004, 39, 425-439. [CrossRef]

164. Gustin, J.L.; Loureiro, M.E.; Kim, D.; Na, G.; Tikhonova, M.; Salt, D.E. MTP1-dependent Zn sequestration into shoot vacuoles suggests dual roles in $\mathrm{Zn}$ tolerance and accumulation in $\mathrm{Zn}$-hyperaccumulating plants. Plant J. 2009, 57, 1116-1127. [CrossRef]

165. Küpper, H.; Kochian, L.V. Transcriptional regulation of metal transport genes and mineral nutrition during acclimatization to cadmium and zinc in the $\mathrm{Cd} / \mathrm{Zn}$ hyperaccumulator, Thlaspi caerulescens (Ganges population). New Phytol. 2010, 185, 114-129. [CrossRef] [PubMed]

166. Ishida, J.K.; Caldas, D.G.; Oliveira, L.R.; Frederici, G.C.; Leite, L.M.P.; Mui, T.S. Genome-wide characterization of the NRAMP gene family in Phaseolus vulgaris provides insights into functional implications during common bean development. Genet. Mol. Biol. 2018, 41, 820-833. [CrossRef] [PubMed]

167. Krämer, U.; Talke, I.N.; Hanikenne, M. Transition metal transport. FEBS Lett. 2007, 581, 2263-2272. [CrossRef] [PubMed]

168. Weber, M.; Harada, E.; Vess, C.; Roepenack-Lahaye, E.V.; Clemens, S. Comparative microarray analysis of Arabidopsis thaliana and Arabidopsis halleri roots identifies nicotianamine synthase, a ZIP transporter and other genes as potential metal hyperaccumulation factors. Plant J. 2004, 37, 269-281. [CrossRef]

169. Oomen, R.J.; Wu, J.; Lelièvre, F.; Blanchet, S.; Richaud, P.; Barbier-Brygoo, H.; Aarts, M.G.; Thomine, S. Functional characterization of NRAMP3 and NRAMP4 from the metal hyperaccumulator Thlaspi caerulescens. New Phytol. 2009, 181, 637-650. [CrossRef]

170. Stein, R.J.; Höreth, S.; de Melo, J.R.F.; Syllwasschy, L.; Lee, G.; Garbin, M.L.; Clemens, S.; Krämer, U. Relationships between soil and leaf mineral composition are element-specific, environment-dependent and geographically structured in the emerging model Arabidopsis halleri. New Phytol. 2017, 213, 1274-1286. [CrossRef]

171. Meyer, C.L.; Pauwels, M.; Briset, L.; Godé, C.; Salis, P.; Bourceaux, A.; Souleman, D.; Frérot, H.; Verbruggen, N. Potential preadaptation to anthropogenic pollution: Evidence from a common quantitative trait locus for zinc and cadmium tolerance in metallicolous and nonmetallicolous accessions of Arabidopsis halleri. New Phytol. 2016, 212, 934-943. [CrossRef]

172. Gonneau, C.; Noret, N.; Gode, C.; Frerot, H.; Sirguey, C.; Sterckeman, T.; Pauwels, M. Demographic history of the trace metal hyperaccumulator Noccaea caerulescens (J. Presl and C. Presl) FK Mey. in Western Europe. Mol. Ecol. 2017, 26, 904-922. [CrossRef]

173. Nowak, J.; Frérot, H.; Faure, N.; Glorieux, C.; Liné, C.; Pourrut, B.; Pauwels, M. Can zinc pollution promote adaptive evolution in plants? Insights from a one-generation selection experiment. J. Exp. Bot. 2018, 69, 5561-5572. [CrossRef]

174. Lin, Y.-F.; Aarts, M.G. The molecular mechanism of zinc and cadmium stress response in plants. Cell. Mol. Life Sci. 2012, 69, 3187-3206. [CrossRef]

175. Chao, Y.-E.; Zhang, M.; Tian, S.-K.; Lu, L.-L.; Yang, X.-E. Differential generation of hydrogen peroxide upon exposure to zinc and cadmium in the hyperaccumulating plant species (Sedum alfredii Hance). J. Zhejiang Univ. Sci. B 2008, 9, 243-249. [CrossRef] [PubMed]

176. Yang, Q.; Shohag, M.; Feng, Y.; He, Z.; Yang, X. Transcriptome comparison reveals the adaptive evolution of two contrasting ecotypes of $\mathrm{Zn/Cd}$ hyperaccumulator Sedum alfredii hance. Front. Plant Sci. 2017, 8, 425. [CrossRef] [PubMed]

177. Deniau, A.; Pieper, B.; Ten Bookum, W.; Lindhout, P.; Aarts, M.; Schat, H. QTL analysis of cadmium and zinc accumulation in the heavy metal hyperaccumulator Thlaspi caerulescens. Theor. Appl. Genet. 2006, 113, 907-920. [CrossRef] [PubMed] 
178. Willems, G.; Dräger, D.B.; Courbot, M.; Godé, C.; Verbruggen, N.; Saumitou-Laprade, P. The genetic basis of zinc tolerance in the metallophyte Arabidopsis halleri ssp. halleri (Brassicaceae): An analysis of quantitative trait loci. Genetics 2007, 176, 659-674. [CrossRef]

179. Sarwar, N.; Imran, M.; Shaheen, M.R.; Ishaque, W.; Kamran, M.A.; Matloob, A.; Rehim, A.; Hussain, S. Phytoremediation strategies for soils contaminated with heavy metals: Modifications and future perspectives. Chemosphere 2017, 171, 710-721. [CrossRef]

180. Li, Y.; Luo, J.; Yu, J.; Xia, L.; Zhou, C.; Cai, L.; Ma, X. Improvement of the phytoremediation efficiency of Neyraudia reynaudiana for lead-zinc mine-contaminated soil under the interactive effect of earthworms and EDTA. Sci. Rep. 2018, 8, 1-10. [CrossRef]

181. Ullah, A.; Heng, S.; Munis, M.F.H.; Fahad, S.; Yang, X. Phytoremediation of heavy metals assisted by plant growth promoting (PGP) bacteria: A review. Environ. Exp. Bot. 2015, 117, 28-40. [CrossRef]

182. Basharat, Z.; Novo, L.A.; Yasmin, A. Genome editing weds CRISPR: What is in it for phytoremediation? Plants 2018, 7, 51. [CrossRef]

(C) 2020 by the authors. Licensee MDPI, Basel, Switzerland. This article is an open access article distributed under the terms and conditions of the Creative Commons Attribution (CC BY) license (http://creativecommons.org/licenses/by/4.0/). 